KATARZYNA GOŁUŃSKA

Instytut Psychologii, Uniwersytet Kazimierza Wielkiego, Bydgoszcz Institute od Psychology, Kazimierz Wielki University, Bydgoszcz e-mail: olunska.kasia@gmail.com

MAGDALENA MIOTK-MROZOWSKA

Instytut Psychologii, Uniwersytet Kazimierza Wielkiego Institute od Psychology, Kazimierz Wielki University, Bydgoszcz mmiotk@ukw.edu.pl

\title{
Znaczenia nadawane urządzeniu dotykowemu przez rodziców małych dzieci w interakcji ja-dziecko-urządzenie mobilne - badanie eksploracyjne
}

\author{
The Meanings Assigned to the Mobile Device by Parents of Young \\ Children in the Me-child-mobile Device Interaction - an Exploratory Study
}

\begin{abstract}
Referring to psychological concepts of child development inspired by the achievements of Lev S. Vygotsky (1971, 2002, 2006) and John Bowlby (2007), the authors formed a procedural model of sensitive teaching. The sensitive teaching model was referenced to experiences with mobile devices reported by families with young children. The presented study explores the meanings assigned by the caregivers to mobile devices in the parent-child-mobile device interaction. The qualitative content analysis of 97 self-narration resulted in seven categories of meaning: (1) educator, (2) amusement, (3) risk, (4) distractor and inhibitor, (5) replacement, (6) regulator of emotions, (7) biological control.
\end{abstract}

Keywords: sensitive teaching, parental sensitivity, mobile devices, early childhood, qualitative content analysis.

Słowa kluczowe: wrażliwe nauczanie, wrażliwość rodzicielska, urządzenia mobilne, wczesne dzieciństwo, jakościowa analiza treści.

\section{WPROWADZENIE}

Coraz częściej w domach z małymi dziećmi, obok osób dorosłych, użytkownikiem nowych technologii staje się ich najmłodszy członek rodziny (Bąk, 2015; Chaudron, 2015; Ólafsson, Livingstone, Haddon, 2013; Staksrud, Livingstone, Haddon, Ólafsson, 2009). Sprzyja temu technologia ekranów dotykowych i idea mobilności urządzeń stosowana w produkcji tabletów i smartfonów (Radesky, Schumacher, Zuckerman, 2015). Stwarza to specyficzną sytuację, podobną do interakcji społecznej, w przebiegu której wzajemnie oddziałują na siebie rodzic, dziecko i urządzenie dotykowe ${ }^{1}$.

Pojęcie interakcji społecznej rozumiemy jako proces obejmujący świadome, powtarzalne zachowania interpersonalne, w przebiegu którego uczestnicy podzielają percepcję sytuacji i wzajemnie zaspokajają swoje potrzeby - a jego 
dynamika zależy zarówno od właściwości podmiotowych partnerów, jak i cech aktualnej sytuacji (Miotk-Mrozowska, 2011). Ponadto, mimo swej dynamicznej natury, interakcja społeczna odzwierciedla trwałe związki międzyludzkie leżące u jej podłoża - stosunek społeczny (związek oparty na obiektywnych zasadach funkcjonowania w danej sytuacji społecznej, np. normach, rolach społecznych, regulaminach) oraz relację interpersonalną (związek silnie nasycony wzajemnym ustosunkowaniem emocjonalnym, oparty na właściwościach psychologicznych osób, m.in. cechach osobowości, postawach społecznych, systemie wartości) (Heider, 1958; Miotk-Mrozowska, 2011).

Uznajemy za nieuprawnione traktowanie obiektu fizycznego jako partnera interakcji, jesteśmy natomiast skłonne przyznać urządzeniom mobilnym status obiektu interakcji. Zasadność takiego podejścia opieramy na tezach interakcjonizmu symbolicznego, z którego wywodzi się pojęcie „definicji sytuacji” (ang. definition of the situation), uważanej za nadrzędny proces determinujący działania ludzi w sytuacjach społecznych (Blumer, 1969). Definicja sytuacji to aktywny proces określania jej znaczenia poprzez identyfikowanie obiektów interakcji (fizycznych, społecznych, abstrakcyjnych) i ocenianie ich ważności ze względu na planowane działanie (Blumer, 1969). John P. Hewitt podkreślał nie tylko dynamiczny, ale też strukturalny charakter tego zjawiska, pisząc, że „,definicja sytuacji jest organizacją percepcji, w której ludzie łączą obiekty, znaczenia i innych, i działają wobec nich w koherentny zorganizowany sposób" (1979, s. 72). Można zatem założyć, że zachowanie rodzica jest aktywnie kształtowane na podstawie znaczeń przypisywanych przez niego zarówno dziecku, jak i urządzeniu dotykowemu (obiektom interakcji). Ważnym problemem jest więc określenie, jakie znaczenia rodzice nadają tabletowi bądź smartfonowi oraz jakie, w związku z nadanym znaczeniem, cele próbują realizować $\mathrm{w}$ interakcji ja-dziecko-urządzenie mobilne.

Przyjęta perspektywa teoretyczna pozwala na rozważania nad takimi elementami interakcji rodzic-dziecko-urządzenie dotykowe, jak: właściwości podmiotowe rodzica jako partnera interakcji, potrzeby partnerów zaspokajane we wspomnianej interakcji oraz podzielanie percepcji (ang. shared perceptions) sytuacji pomiędzy rodzicem i dzieckiem - w związku z tym dalsze rozważania ulokowane zostały w założeniach teorii społeczno-kulturowej Lwa S. Wygotskiego $(1971,2002,2006)$ oraz teorii przywiązania Johna Bowlby'ego (2007).

\section{Potrzeby zaspokajane w interakcji - otoczenie fizyczne malego dziecka a wrażliwość rodzicielska}

Richard D. Ryan i Edward L. Deci (2000) wskazali na trzy uniwersalne potrzeby rozwojowe człowieka: potrzebę więzi, autonomii i kompetencji. Ich zaspokojeniu służą dwa antytetyczne i komplementarne systemy behawioralne: system przywiązania oraz system eksploracji i poszukiwania bodźców (Ainsworth, Bell, 1970; Ainsworth, Blehar, Waters, Wall, 1978; Bowlby, 2007). W życiu dziecka zachowania przywiązaniowe i eksploracja przeplatają się nieustannie (Ainsworth, Bell, 1970). Rolą rodzica jest odczytanie sygnałów płynących od dziecka, a świadczących o jego aktualnych potrzebach, oraz właściwa odpowiedź w ramach uruchomionego przez dziecko systemu. O tym, w jakim stopniu rodzic będzie do tego zdolny, decyduje poziom wrażliwości rodzicielskiej (ang. parental sensitivity), czyli zespołu poznawczych, emocjonalnych i społecznych kompetencji opiekuna, decydujących o tym, czy opiekun: (1) stale ukierunkowuje uwagę na możliwe sygnały płynące od dziecka, (2) jest zdolny do dostrzegania sygnałów wysłanych przez dziecko, (3) właściwe je interpretuje, (4) natychmiastowo i odpowiednio reaguje na sygnały (Ainsworth i in., 1978; Bowlby, 2007; Czub, 2005b; Grossmann, Grossmann, Waters, 2005; Grossmann, Bretherton, Waters, Grossmann, 2013).

Interakcja rodzic-dziecko-urządzenie mobilne sprzyja uruchomieniu systemu eksploracji u dziecka. Podkreślić należy, że dla przestrzeni fizycznej małego dziecka funkcję organizującą spełnia jego otoczenie społeczne, ponieważ: (1) to opiekunowie aranżują przestrzeń dziecka i decydują o doborze otaczających je przedmio- 
tów oraz (2) nadają znaczenie udostępnionym dziecku przedmiotom (Hornowska, Brzezińska, Appelt, Kaliszewska-Czeremska, 2014). Według H. Rudolpha Schaffera od piątego miesiąca życia dziecka dotychczasowe kontakty matka-dziecko zmieniają swój charakter na sytuację niemowlę-matka-przedmiot (Schaffer, 1994b). Wspomniana zmiana daje rodzicom możliwość wpływania na dziecko nie tylko w sposób bezpośredni, ale i przez oddziaływanie pośrednie, czyli określanie miejsc, do których dziecko ma dostęp, oraz wybór przedmiotów, którymi dziecko może się zajmować (Bradley, Burchinal, Casey, 2001; Schaffer, 1994b). Działania podjęte przez rodzica będą wyznaczane jego komfortem bądź dyskomfortem, odczuwanym wobec dynamicznego wzrostu umiejętności eksploracji otoczenia u dziecka.

\section{Podzielanie percepcji sytuacji - narzędzia kultury i upośrednianie znaczenia w relacji rodzic-dziecko}

Lew Wygotski (1971, 2002, 2006) zakładał, że rozwój dziecka przebiega w kierunku od funkcjonowania interpersonalnego do intrapsychicznego, natomiast przekaz interpersonalny zawiera się w szerszym kontekście społeczno-kulturowym (Schaffer, 2005). Rodzice wprowadzają dziecko w kulturę poprzez narzędzia kulturowe, czyli wszystkie te przedmioty, umiejętności i wartości, które okazały się użytecznym sposobem przekazywania wiedzy i regulowania stosunków między ludźmi (Filipiak, 2011; Schaffer, 2005; Wood; 2006; Wygotski, 2006). Dziecko przyjmuje narzędzia kulturowe początkowo upośrednione ${ }^{2}$ przez rodzica, następnie podczas procesu rozwoju ontogenetycznego internalizuje je, uwewnętrzniając systemy znaczeniowe dorosłego, dzięki czemu docelowo zyskują one funkcję kierowania procesami psychicznymi i zachowaniem dziecka (Brown, Ferrara, 1994; Smykowski, 2003; Wygotski, 2006). Oznacza to, że systemy znaczeniowe używane przez dorosłych wobec otaczających przedmiotów mają moc konstruowania kontekstu, wewnątrz którego rozwija się dziecko, a upośrednianie znaczenia $^{3}$ jest jednym $z$ ważnych mechanizmów roz- woju człowieka (Klein, 1994; Shotter, 1994; Wygotski, 2006).

Wagę uwspólniania znaczeń (ang. mediated meaning) podkreślał w swojej koncepcji George H. Mead (1975), który wprowadził pojęcie obiektów jako doświadczeń obdarzonych znaczeniem. Samo znaczenie uważał natomiast za nierozerwalnie związane $\mathrm{z}$ działaniem społecznym, podkreślał jego intersubiektywność (Mead, 1975). Ponadto G. H. Mead (1975) uznawał pewną stałość i uniwersalność przekazywanych znaczeń, wynikającą z uczestnictwa w kulturze, szczególnie zaś posługiwania się jej nośnikiem, czyli komunikacją językową.

Stanowisko to jest spójne $\mathrm{z}$ tezami teorii społeczno-kulturowej, która język uznaje za podstawowe narzędzie transmisji kulturowej (Schaffer, 2005; Wood, 2006; Wygotski, 2006). Wraz z rozwojem nowoczesnych technologii komunikacyjnych (Miotk-Mrozowska, 2009; Miotk-Mrozowska, 2011), zmieniają się wymagania stawiane współczesnym rodzicom. Obok naturalnych procesów oddziaływań rodzicielskich, którymi dotychczas były procesy edukacji i socjalizacji (Kaja, 2010), rodzice stają przed trudnym zadaniem ukształtowania najpierw u siebie, a wtórnie u dziecka zupełnie nowego rodzaju kompetencji językowych i komunikacyjnych, jakimi są kompetencje cyfrowe (por. Siuda, Sunża, 2012, s. 11-20) - ze względu na specyfikę tej sytuacji dla określenia tego procesu można przyjąć klasyczne pojęcie tutoringu (Wygotski, 1971).

Pojawia się zatem pytanie o wyznaczniki gotowości do rozpoczęcia takiej nauki po stronie rodzica i dziecka. W odniesieniu do dziecka najczęściej dyskutuje się nad wiekiem inicjacji korzystania z nowych technologii (Bąk, 2015; Radesky, Schumacher, Zuckerman, 2015). Jeśli zaś chodzi o rodziców, można przyjąć, że to, na jakim etapie życia dziecka rodzic podejmie rolę tutora we wspomnianym obszarze, zależy od cech podmiotowych rodzica, z których dwie zasługują na szczególną uwagę. Są to: (1) identyfikacja rodzica z pokoleniem cyfrowych imigrantów/cyfrowych tubylców (Prensky, 2001), (2) kompetencje w obszarze wrażliwego nauczania (Filipiak, 2011; Schaffer, 2005; Wood, 1995). Należy także wspomnieć o niewątpliwie 
istotnej roli, jaką w omawianym procesie odgrywają czynniki sytuacyjne (np. dostęp rodziny do nowych technologii).

\section{Rodzice jako cyfrowi imigranci versus cyfrowi tubylcy}

Marc Prensky (2001) zaproponował podział współczesnych użytkowników nowych technologii na dwie grupy, nazywając je metaforycznie pokoleniem cyfrowych tubylców (ang. digital natives) oraz pokoleniem cyfrowych imigrantów (ang. digital immigrants). Dla cyfrowych tubylców charakterystyczne jest istnienie w świecie komputerów, gier i Internetu $\mathrm{w}$ roli native speakerów (Prensky, 2001). W opozycji do nich cyfrowi imigranci próbują przyswoić obcy język cyfrowego świata, jednak nie wzrastali w nim od początku życia. Stąd jego roli nie odbieraja jako tak istotnej, nie czują się w nim pewnie i swobodnie.

Ellen Helsper i Rebecca Eynon (2009) zakwestionowały kryterium podziału pokoleń wybrane przez Prensky’ego, ponieważ był nim jedynie rok urodzenia - osoby, które przyszły na świat po 1980 roku, zaklasyfikował on do cyfrowych tubylców, osoby urodzone wcześniej - do cyfrowych imigrantów. Badaczki ustaliły, że różnorodne zastosowania nowych technologii w życiu codziennym, poczucie kompetencji cyfrowych, edukacja w tym zakresie i zgromadzone doświadczenie w pracy z nowymi technologiami, powodują, że osoby ze starszych pokoleń dołączają pod względem poziomu kompetencji cyfrowych do osób urodzonych w ostatnich dwóch-trzech dekadach (Helsper, Eynon, 2009).

\section{WRAŻLIWE NAUCZANIE}

Pojęcie wrażliwego nauczania wywodzi się z teorii dwóch stref rozwoju autorstwa L.S. Wygotskiego (1971), który dynamikę rozwoju dziecka opisał z użyciem oryginalnych pojęć - strefy najbliższego i aktualnego rozwoju. Wygotski zdefiniował strefę najbliższego rozwoju (SNR) jako „odległość pomiędzy aktualnym poziomem rozwoju, określonym przez indywidualne rozwiązywanie problemów, a poziomem rozwoju potencjalnego, określonym przez rozwiązy- wanie problemów przy pomocy dorosłych lub bardziej doświadczonych rówieśników" (Wygotski, 2002b, s. 88). Dla porównania strefa aktualnego rozwoju dotyczy wszystkich tych zadań, które dziecko wykonuje samodzielnie, bez pomocy z zewnątrz.

Kontynuacja rozważań zainspirowanych koncepcją Wygotskiego dotyczyła interakcji zachodzących w strefie najbliższego rozwoju. Istotne miejsce zajęło w nich pojęcie wrażliwego nauczania, które H.R. Schaffer zdefiniował jako nastawienie rodzica ${ }^{4}$ na właściwości dziecka $\mathrm{i}$ istotne sygnały związane $\mathrm{z}$ zadaniem napływające od niego, przy jednoczesnym ukierunkowaniu zadania na strefę najbliższego rozwoju (Schaffer, 1994d; 2005). Wrażliwe nauczanie, tak jak je rozumiemy, jest więc pojęciem szerszym aniżeli pojęcie tutoringu. Zawiera w sobie zdolność rodzica do działania w strefie najbliższego rozwoju dziecka, przy jednoczesnym wyczuleniu na różnicowanie i właściwą odpowiedź wobec sygnałów potrzeb eksploracji i przywiązania wysyłanych przez dziecko. Każdego z dorosłych realizującego proces edukacji i pozostającego w specyficznym układzie interakcyjnym z dzieckiem można zatem ulokować na kontinuum wrażliwości nauczania. Szczególne znaczenie dla skuteczności procesu wrażliwego nauczania ma zdolność rodzica do korekty zadania i poziomu własnego zaangażowania w rozwiązanie problemu, wyrażona w ramach informacji zwrotnej kierowanej do dziecka (Brown, Ferrara, 1994). Uogólniając, wobec sukcesów dziecka rodzic powinien zmniejszać własną kontrolę i stopniowo dokonywać transferu odpowiedzialności na dziecko, zaś wobec niepowodzeń dziecka adekwatnie zwiększać własną aktywność (Wood, 1995).

Proces wrażliwego nauczania zostaje uruchomiony przez zachowanie antycypujące - przejawiane w kierowanych do dziecka zadaniach nastawienie rodzica, który traktuje dziecko, jakby było osobą bardziej dojrzałą niż jest w rzeczywistości (Schaffer, 1994a; Wood, 2006). Zachowania antycypujace pełnią dwie istotne funkcje. Po pierwsze, rodzic dzięki nim diagnozuje stan rozwoju dziecka i jego gotowość do bycia traktowanym jako bardziej dojrzałe. Inaczej mówiąc, rodzic na bieżąco sprawdza podatność dziecka na nauczanie w danym obszarze. Po drugie, rodzic 
przygotowuje łagodne przejście dziecka na wyższy poziom umiejętności - wcześniej zaznajamia dziecko z wymaganiami, procedurą, naturą umiejętności, które ma w przyszłości nabyć (Schaffer, 1994a). Rolą zachowań antycypujących jest nie tylko uruchamianie, ale także podtrzymywanie wrażliwego nauczania.

\section{PROBLEM BADAŃ}

Podsumowując dotychczasowe rozważania teoretyczne, wrażliwe nauczanie definiujemy jako proces ukierunkowany na stymulację rozwoju dziecka poprzez podejmowanie działań w obrębie jego strefy najbliższego rozwoju, a działający na zasadzie sprzężeń zwrotnych uruchamianych $\mathrm{w}$ interakcji rodzic-dziecko. Jego przebieg obrazuje rysunek 1 .

Zdarzeniem uruchamiającym pętlę jest (1) wystąpienie zachowania antycypującego ze strony rodzica, które (2) po stronie dziecka wywołuje reakcję zwrotną. Na jej podstawie rodzic (3) diagnozuje poziom rozwoju dziecka, jego gotowość do podjęcia zadania i (4) podejmuje decyzję co do korekty zachowania antycypującego w formie: (a) wycofania zadania, (b) podniesienia trudności zadania przy zmniejszeniu własnej aktywności, (c) obniżenia trudności zadania przy zwiększeniu własnego zaangażowania lub (d) utrzymania trudności zadania i kontroli nad zadaniem na obecnym poziomie. W przypadku wycofania zadania dochodzi do przerwania procesu, w innych wypadkach rodzic (5) ponawia zachowanie antycypujące w celu ewaluacji dokonanej korekty zadania $\mathrm{w}$ odniesieniu do strefy najbliższego rozwoju dziecka.

By zwiększyć możliwości eksplanacyjne powyższego modelu, odwołamy się do przywołanego wyżej pojęcia wrażliwości rodzicielskiej i sygnalizowanej wagi nadawania znaczenia urządzeniu mobilnemu.

Wrażliwe nauczanie w odniesieniu do rodzica, to pojęcie łączące w sobie cechę podmiotową, jaką jest wrażliwość rodzicielska, z kontekstem oddziaływań na przebieg naturalnych procesów życiowych u dziecka, jakimi są

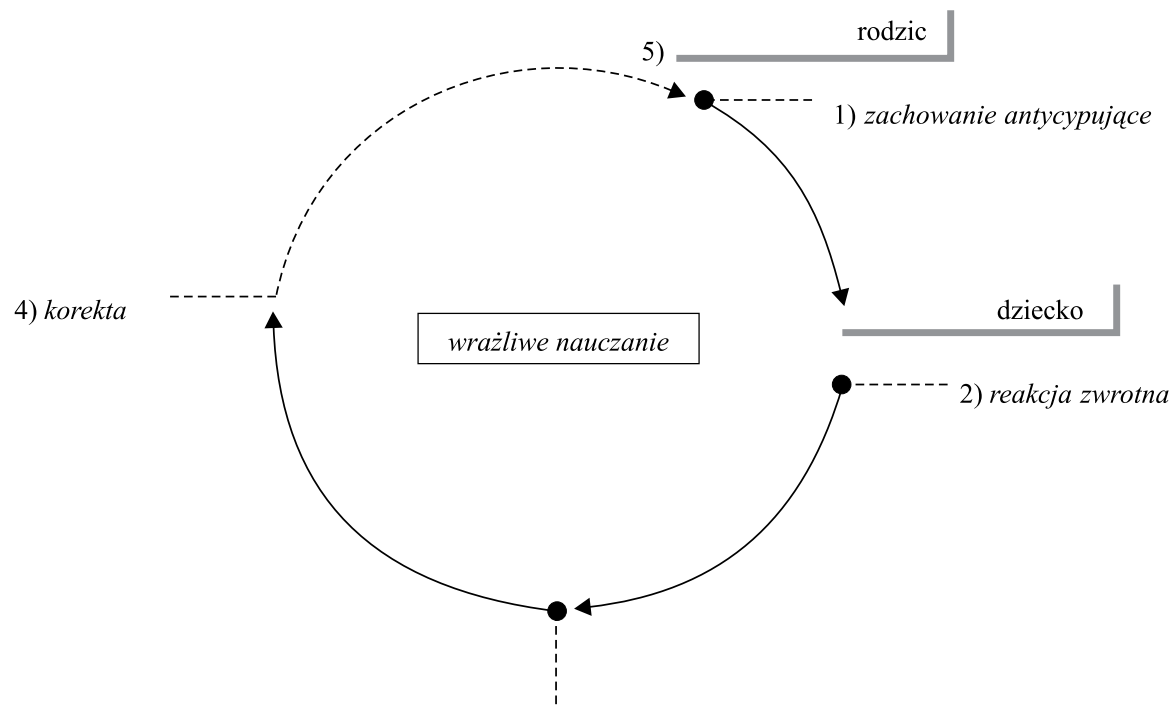

3) odbiór i analiza

rodzic

Rysunek 1. Pętle sprzężenia zwrotnego w procesie wrażliwego nauczania w interakcji rodzic-dziecko Źródło: opracowanie własne na podstawie: Schaffer (1994, 2005); Wood (1995); Wygotski (1971, 2002, 2006). 
edukacja i socjalizacja. Zakładamy, że bez wysokiego poziomu wrażliwości rodzicielskiej nie jest możliwe zaistnienie wrażliwego nauczania.

W kontekście dotychczasowego wywodu zasadne wydaje się zatem sformułowanie pytania o potencjalne korelaty wrażliwego nauczania w interakcji rodzic-dziecko-urządzenie mobilne. Opierając się na przedstawionych wyżej założeniach teoretycznych, postawiłyśmy hipotezę, że jednym z czynników potencjalnie związanych z gotowością do posługiwania się procesem wrażliwego nauczania przez rodzica jest znaczenie nadawane przez rodzica urządzeniu mobilnemu jako obiektowi interakcji (rysunek 2).

W celu weryfikacji tej hipotezy zaprojektowałyśmy i przeprowadziłyśmy badanie eksploracyjne. Wstępny etap badania ukierunkowany był na: (1) empiryczną eksplorację owych znaczeń i wskazanie ich roli w zaproponowanym modelu teoretycznym oraz (2) poszukiwanie podstaw do formułowania kolejnych hipotez dotyczących potencjalnych związków tych znaczeń z poziomem wrażliwości nauczania rodzicielskiego. Ze względu na eksploracyjny charakter badania celem nadrzędnym było opracowanie kategorii i klucza kodowego, według których w przyszłych badaniach możliwe będzie przeprowadzanie kodowania znaczenia nadawanego urządzeniom mobilnym w interakcji ja-dziecko-urządzenie dotykowe przez rodziców mających dzieci w okresie wczesnego dzieciństwa.

W związku z tym, sformułowałyśmy następujące pytania badawcze:

1. Jakie znaczenia rodzice małych dzieci nadają urządzeniu dotykowemu w interakcji rodzic-dziecko-urządzenie mobilne (dotykowe)?

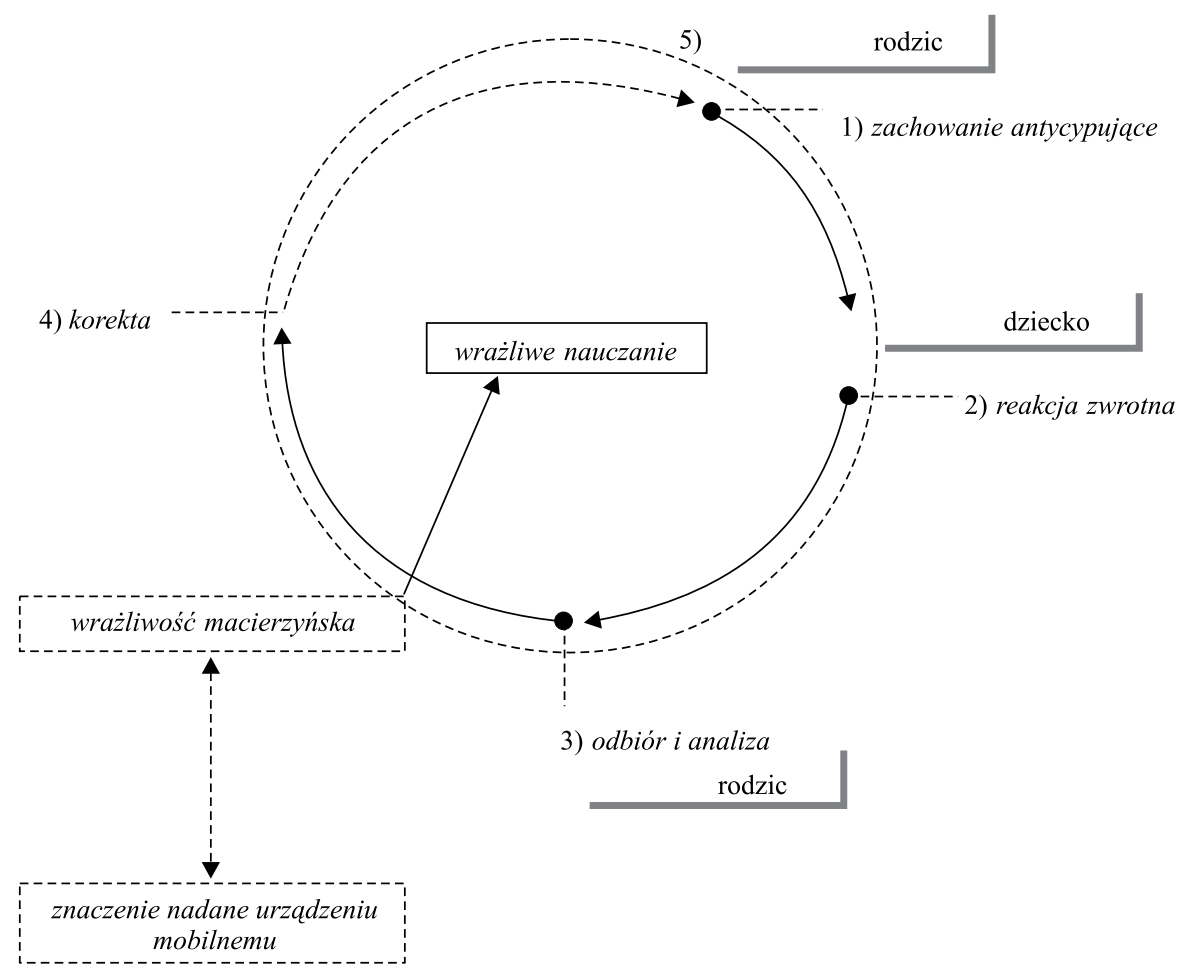

Rysunek 2. Model procesualny wrażliwego nauczania uwzględniający wrażliwość rodzicielską oraz nadawanie znaczeń urządzeniu mobilnemu jako obiektowi interakcji ja-dziecko-urządzenie mobilne 
2. Jakie czynniki podmiotowe po stronie rodzica towarzyszą nadawaniu poszczególnych znaczeń urządzeniu dotykowemu w interakcji rodzic-dziecko-urządzenie mobilne?

3. Jakie czynniki sytuacyjne towarzyszą nadawaniu poszczególnych znaczeń urządzeniu dotykowemu w interakcji rodzic-dzieckourządzenie mobilne?

4. Jakie cele próbują realizować rodzice w interakcji ja-dziecko-urządzenie mobilne?

$\mathrm{W}$ celu odpowiedzi na tak sformułowane pytania przeprowadziłyśmy badanie pilotażowe. W dalszej części opracowania przedstawiona zostanie metodologia i uzyskane rezultaty badania.

\section{METODA}

Zastosowaną techniką badawczą była jakościowa analiza treści, w której za jednostkę analizy przyjęłyśmy epizod narracji. Dobór metody jakościowej był podyktowany jej przydatnością w badaniach eksploracyjnych. Analizowano aspekt znaczeniowy wypowiedzi rodziców, opierając się na zasadzie koła hermeneutycznego, to znaczy odnosząc autonarrację dotyczącą interakcji ja-dziecko-urządzenie dotykowe do całości wypowiedzi i krążąc od całości tekstu do jego części i z powrotem, w celu niestronniczego zinterpretowania przekazywanych znaczeń ${ }^{5}$ (Krejtz, Krejtz, 2005a; Soroko, 2007). Przyjęłyśmy perspektywę psychologii narracyjnej, zgodnie z którą w narracjach osobistych człowiek ujawnia nie tylko treść własnych, bezpośrednich, codziennych doświadczeń, ale także odsłania znaczenia i sens, które przypisał poszczególnym zdarzeniom (Straś-Romanowska, Bartosz, Żurko, 2010).

Dodatkowo wyodrębniając w trakcie badań kategorie znaczeniowe, opierałyśmy się na metodologii teorii ugruntowanej opisującej zbieranie danych, budowanie hipotez $\mathrm{i}$ ich weryfikację, jako procesy nierozdzielne, które wielokrotnie wpływają na siebie w trakcie generowania teorii (ang. generation of theory; Glaser, Strauss, 2009). W trakcie analizy dane empiryczne bezpośrednio odnosiłyśmy do obserwowanego fragmentu rzeczywistości społecznej, czyli rzeczywistości polskich rodziców mających dzieci w okresie wczesnego dzieciństwa rodziców, którzy korzystają z nowych technologii (Glaser, Strauss, 2009).

\section{MATERIAL BADAWCZY}

Próbę do badań pozyskałyśmy poprzez zgromadzenie źródeł archiwalnych dostępnych w internecie w postaci wypowiedzi na forach internetowych, blogach i portalach skupiajacych rodziców dzieci w okresie wczesnego dzieciństwa lub dotyczących nowych technologii. Sposób gromadzenia danych do analizy podyktowany był trzema założeniami: (1) chęcią zebrania spontanicznych, naturalnych narracji rodziców, (2) potrzebą zmniejszenia oddziaływania osoby badacza na treść wypowiedzi, w obawie o poszukiwanie przez rodziców aprobaty społecznej z jego strony, (3) oczekiwaniem zwiększonej szczerości wypowiedzi dzięki jej anonimowości.

Analizie poddałyśmy wypowiedzi pochodzące $\mathrm{z}$ wątków $\mathrm{z}$ internetowych grup dyskusyjnych, jak również wpisy na blogach lub komentarze osób odnoszące się do danej wypowiedzi, których lista znajduje się w Załączniku 1 do niniejszego artykułu. Kryteriom włączenia do próby badanej odpowiadało 97 wypowiedzi, z których najwcześniejsza była datowana na 12 września 2013 roku, najstarsza na 15 kwietnia 2016 roku. Wypowiedzi pozyskałyśmy z: siedmiu wątków na forach internetowych, z których włączono do analizy znaczeniowej 27 wypowiedzi; 27 blogów, z których włączono do analizy 70 wypowiedzi pochodzących z postów lub komentarzy odnoszących się do postów.

\section{PROCEDURA}

Przeprowadzone badanie miało charakter pilotażowy i eksploracyjny, jego celem było określenie znaczeń nadawanych urządzeniom mobilnym przez rodziców w interakcji jadziecko-urządzenie dotykowe, co wiązało się z opracowaniem kategorii nadawanych znaczeń i klucza kodowego. Ponadto nacisk położyłyśmy na poszukiwanie hipotez dotyczących związku wyodrębnionych znaczeń z poziomem wrażliwości nauczania rodzicielskiego. Bada- 
nie przeprowadziłyśmy w okresie od marca do sierpnia 2016 roku.

Analiza aspektu znaczeniowego treści obejmowała cztery etapy:

1. Etap pobrania próbki (ang. sampling): Zdefiniowałyśmy obszar pozyskiwania źródeł archiwalnych. Następnie do próby badanej włączyłyśmy narracje spełniające następujące wytyczne: (a) osoba w wypowiedzi opisała własne doświadczenia w sytuacjach ja-dziecko-urządzenia mobilne spełniając kryterium narracyjności ${ }^{6},(\mathrm{~b})$ analiza adresu IP, z którego wygenerowano wypowiedź, wskazywała na unikalnego, niepowtarzającego się względem poprzednich użytkownika, (c) wypowiedź wskazywała na wiek dziecka równy lub powyżej 10 miesiąca, jednak nie wyższy niż 48 miesiąc życia dziecka (d) oraz jednoznacznie określała, że osoba wypowiadająca się jest rodzicem opisywanego dziecka. Początek epizodów narracji wyznaczało: rozpoczęcie relacjonowania własnego doświadczenia interakcji ja-dziecko-urządzenie mobilne; i/lub relacjonowanie własnych opinii na temat nowych technologii; i/lub relacjonowanie opinii innych lub polemizowanie z opiniami innych na temat nowych technologii czy też interakcji dziecka z nowymi technologiami. Koniec epizodu narracji wyznaczało przejście do innego niż wyżej wymienione tematy wypowiedzi. Dokonałyśmy wyodrębnienia jednostek znaczeniowych (ang. idea units) zgodnie z przyjętym kryterium ich tematycznego powiązania $\mathrm{z}$ interakcja ja-dzieckourządzenie mobilne (Soroko, 2007).

2. Etap tworzenia kategorii: Uzyskane jednostki znaczeniowe poddałyśmy analizie w celu wygenerowania na ich podstawie kategorii, określających znaczenia, jakie rodzice nadają urządzeniu mobilnemu w interakcji ja-dziecko-urządzenie dotykowe. Stosowałyśmy założenia i metodologię teorii ugruntowanej (metoda ciagłego porównywania; Glaser, Strauss, 2009), stąd hipotezy dotyczące kategorii i ich własności, były przez nas wielokrotnie modyfikowane i weryfikowane, a same kategorie, jako konstrukty teoretyczne, były pochodną stale powtarzanych analiz empirycznych.
3. Etap tworzenia klucza kodowego: Opracowałyśmy reguły kodowania, określając etykiety kategorii, definicje kategorii i ich wskaźniki (podmiotowe i sytuacyjne), oraz uzupełniłyśmy klucz o zakodowane przykłady epizodów narracji. Ostatecznie utworzyłyśmy siedem nierozłącznych kategorii nadawanych znaczeń.

4. Etap sprawdzania rzetelności klucza kodowego: $\mathrm{W}$ analizie 20 losowo dobranych próbek dokonanej przy użyciu siedmiokategorialnego klucza kodowego wzięło udział dwóch niezależnych sędziów kompetentnych ${ }^{7}$. Do określenia rzetelności użyłyśmy współczynnika zgodności pi $(\pi)$ Scotta, który został stworzony do obliczania zgodności między dwoma sędziami, kategoryzującymi dane na skali nominalnej, i uwzględnia jednocześnie wpływ przypadkowej zgodności (Krejtz, Krejtz, 2005b). Uzyskałyśmy zadowalający współczynnik zgodności $\pi=, 72^{8}$, jednak aktualna postać klucza będącego wynikiem badań eksploracyjnych wymaga dalszego opracowania merytorycznego i metodologicznego.

\section{WYNIKI}

Dobór próby i przyjęcie założeń teorii ugruntowanej pozwoliły na budowanie uogólnień o średnim zasięgu, czyli dotyczących konkretnej zbiorowości - polskich rodziców małych dzieci, którzy korzystają z nowych technologii w obecnych warunkach społeczno-kulturowych. Jak wskazuje Emilia Soroko (2010), badanie opierające się na narracjach osobistych odzwierciedla niewatpliwie indywidualne znaczenia, ale także doświadczenie kolektywne - ,znaczenia istotne dla danej kultury lub otoczenia społecznego" (Soroko, 2010, s. 102).

Uzyskane kategorie znaczeń nadawanych przez rodziców urządzeniu mobilnemu w interakcji rodzic-dziecko-urządzenie dotykowe prezentuje tabela 1 . Natomiast klucz kodowy zawierający ponadto wskaźniki podmiotowe, sytuacyjne i cel działań rodzicielskich towarzyszące nadaniu poszczególnych znaczeń stanowi Załącznik 2 do niniejszego artykułu. 
Tabela 1. Kategorie znaczeń nadawanych urządzeniu dotykowemu wyodrębnione z narracji dotyczących interakcji ja-dziecko-urządzenia mobilne - definicje i przykłady zakodowanych wypowiedzi

\begin{tabular}{|c|c|c|}
\hline Kategoria & Definicja kategorii & $\begin{array}{l}\text { Przyklad zakodowanego } \\
\text { fragmentu wypowiedzi }\end{array}$ \\
\hline edukator & $\begin{array}{l}\text { Urządzenie mobilne jest dla rodzica „edukatorem”, } \\
\text { gdy interakcję ja-dziecko-urządzenie dotykowe po- } \\
\text { strzega jako okazję do atrakcyjnego nauczania dzie- } \\
\text { cka. Głównie poszukuje aplikacji, które ocenia jako } \\
\text { wartościowe edukacyjnie. Stara się zapewnić dziecku } \\
\text { biegłość w obsłudze urządzeń. Odwołuje się do argu- } \\
\text { mentów wskazujących na konieczność przygotowa- } \\
\text { nia dziecka do życia w świecie zdominowanym przez } \\
\text { nowe technologie. Jest dumny, gdy zauważa postępy } \\
\text { dziecka w obsłudze urządzeń dotykowych lub w na- } \\
\text { uce za pośrednictwem aplikacji. Wskazuje na samą } \\
\text { konstrukcję tabletów czy smartfonów jako narzędzi } \\
\text { przydatnych w edukacji małego dziecka (intuicyjna } \\
\text { obsługa, technologia dotykowa). }\end{array}$ & $\begin{array}{l}\text { „Moja córka ma dwa lata: } \\
\text { obsługuje iPhone lepiej niż } \\
\text { ja, włącza sobie sama ulu- } \\
\text { bione bajki. Co z tego ma? } \\
\text { Zna } 9 \text { kolorów po angielsku, } \\
\text { liczy do } 10 \text { również po an- } \\
\text { gielsku, po polsku również } \\
\text { liczy tyle że do } 8 \text {, zna alfa- } \\
\text { bet (po polsku i angielsku)". }\end{array}$ \\
\hline rozrywka & $\begin{array}{l}\text { Urządzenie mobilne jest dla rodzica, „rozrywką”, gdy } \\
\text { interakcję ja-dziecko-urządzenie dotykowe postrzega } \\
\text { jako okazję do zaoferowania dziecku nowej zabawy. } \\
\text { Głównie poszukuje takich możliwości, które ocenia } \\
\text { jako odprężające dla dziecka, wywołujące jego radość } \\
\text { (często są to filmy i bajki). Stara się zapewnić dziecku } \\
\text { rozrywkę za pomocą urządzeń dotykowych. Odwołuje } \\
\text { się do argumentów wskazujących na potrzebę spędza- } \\
\text { nia przez dziecko czasu na różnorodnych aktywnoś- } \\
\text { ciach. Traktuje urządzenia dotykowe jako jedną z cie- } \\
\text { kawych alternatyw dla innych zajęć. Podkreśla, że } \\
\text { nowe technologie służą zabawie zarówno dorosłych, } \\
\text { jak i dzieci. }\end{array}$ & $\begin{array}{l}\text { „Cudowny post, moja córcia } \\
\text { też prawie 4-latka też ma } \\
\text { tablet a jest małą fanka Elsy } \\
\text { więc uwielbia oglądać i słu- } \\
\text { chać «Mam tę moc» raz za } \\
\text { razem :) we wszystkich ję- } \\
\text { zykach albo filmiki z lepie- } \\
\text { niem ciastoliny. Nie uważam } \\
\text { że robię jej krzywdy pozwa- } \\
\text { lając na korzystanie z tabletu } \\
\text { od czasu do czasu”. }\end{array}$ \\
\hline zagrożenie & $\begin{array}{l}\text { Urządzenie mobilne jest dla rodzica ,,zagrożeniem”, } \\
\text { gdy interakcję ja-dziecko-urządzenie dotykowe } \\
\text { postrzega jako niekorzystną dla obecnego rozwo- } \\
\text { ju dziecka. Podkreśla, że nowe technologie nie są } \\
\text { odpowiednią zabawką dla dzieci. Wskazuje, że ma } \\
\text { zamiar wprowadzić je później do życia dziecka. Czę- } \\
\text { sto za wzór wychowania stawia własne dzieciństwo } \\
\text { lub czasy, gdy dzieci żyły bez dostępu do tabletów, } \\
\text { smartfonów, komputerów. Powołuje się na opinie } \\
\text { ekspertów dotyczące ich niekorzystnego wpływu na } \\
\text { rozwój dziecka. Jest dumny z wychowywania dzie- } \\
\text { cka bez dostępu lub z bardzo ograniczonym dostę- } \\
\text { pem do urządzeń dotykowych, podkreśla własne } \\
\text { kompetencje w atrakcyjnym organizowaniu czasu } \\
\text { dziecka „bez ekranów” (unplugged). Jest niezadowo- } \\
\text { lony, gdy inne bliskie osoby umożliwiają dostęp do } \\
\text { nowych technologii jego dziecku, np. podczas jego } \\
\text { nieobecności, bądź odczuwa wyrzuty sumienia, je- } \\
\text { śli pozwala dziecku na taką zabawę, obwinia siebie, } \\
\text { uważa, że szkodzi tym dziecku. }\end{array}$ & $\begin{array}{l}\text { „Mam fisia na punkcie tema- } \\
\text { tu dziecko a ekran bo znam } \\
\text { kilka przypadków doro- } \\
\text { słych już ludzi, którzy są od } \\
\text { komputera/komórki ciężko } \\
\text { uzależnieni i przez to trudno } \\
\text { im funkcjonować w realu. } \\
\text { Dlatego boję się o moją } \\
\text { dwulatkę [...]. Z doświad- } \\
\text { czenia wiem, że czego oczy } \\
\text { nie widzą, tego sercu nie } \\
\text { żal, więc komórkę staram } \\
\text { się trzymać pod zasięgiem } \\
\text { bystrych oczek, TV nie włą- } \\
\text { czamy, w podróż samocho- } \\
\text { dem zabieramy książeczki } \\
\text { i kolorowanki”. }\end{array}$ \\
\hline
\end{tabular}




\begin{tabular}{|c|c|c|}
\hline $\begin{array}{l}\text { dystraktor } \\
\text { i hamulec }\end{array}$ & $\begin{array}{l}\text { Urządzenie mobilne jest dla rodzica ,dystraktorem } \\
\text { i hamulcem”, gdy interakcje ja-dziecko-urządze- } \\
\text { nie dotykowe postrzega jako okazję do sprawowania } \\
\text { kontroli nad cechami jego procesu uwagi (trwałością, } \\
\text { zakresem, przerzutnością, podzielnościa) lub sprawo- } \\
\text { wania kontroli nad jego zachowaniami eksploracyjny- } \\
\text { mi. Rodzic odwraca uwagę dziecka od świadomego } \\
\text { doświadczania danej czynności czy sytuacji i kieruje } \\
\text { ją na urządzenie dotykowe. Wykorzystuje urządzenie } \\
\text { mobilne wtedy, gdy sytuacja jego zdaniem wymaga } \\
\text { zahamowania eksploracji dziecka, np. gdy potrzebne } \\
\text { jest pozostawanie w jednym miejscu czy niedotyka- } \\
\text { nie otaczających przedmiotów. Zyskuje tym samym } \\
\text { łatwość w przeprowadzaniu czynności opiekuńczych, } \\
\text { np. pielęgnacyjnych, i dyscyplinowaniu dziecka. Czę- } \\
\text { sto rodzic podkreśla, że bez „pomocy” urządzenia do- } \\
\text { tykowego nie mógłby skutecznie kontrolować dziecka } \\
\text { w danym momencie, np. przy obcinaniu włosów. }\end{array}$ & $\begin{array}{l}\text { „Stąd moje wahanie, ale } \\
\text { inaczej inhalacji dziecku nie } \\
\text { dawaliśmy rady robić, tylko } \\
\text { z Reksiem czy Pszczólką } \\
\text { Mają (v.2013 ;) na YT, więc } \\
\text { się nauczyła. Nigdy sama, } \\
\text { zawsze ktoś obok i staram } \\
\text { się jej opowiadać, ale mimo } \\
\text { wszystko granica ściśle trzy- } \\
\text { mana, mimo protestów”. } \\
\text { „Poza tym korzystam w sy- } \\
\text { tuacjach podbramkowych, } \\
\text { np. u lekarza, gdy wszyst- } \\
\text { kie inne sposoby zawdodzą } \\
\text { to np. oglądamy zdjęcia na } \\
\text { komórce”. }\end{array}$ \\
\hline $\begin{array}{l}\text { regulator bio- } \\
\text { logiczny }\end{array}$ & $\begin{array}{l}\text { Urządzenie mobilne jest dla rodzica „regulatorem } \\
\text { biologicznym”, gdy interakcję ja-dziecko-urządze- } \\
\text { nie dotykowe postrzega jako możliwość regulowania } \\
\text { jego cyklu snu-czuwania oraz spożywania posiłków. } \\
\text { Rodzic udostępnia dziecku urządzenie mobilne, by za- } \\
\text { pobiec zaśnięciu, lub przeciwnie, by je uśpić, także by } \\
\text { budować dzięki niemu codzienne rytuały dziecka. De- } \\
\text { cyduje się na karmienie dziecka z użyciem urządzenia } \\
\text { dotykowego, gdy całkowicie odmawia ono przyjęcia } \\
\text { pokarmu, lub by wymóc na nim dokończenie posiłku } \\
\text { czy zjedzenie określonej porcji lub pokarmu. }\end{array}$ & $\begin{array}{l}\text { „Kiedy jadę z } 11 \text {-miesięcz- } \\
\text { nym autem po południu i nie } \\
\text { chce by zasnął włączam mu } \\
\text { Teletubisie i nie ma w tym } \\
\text { nic złego”. }\end{array}$ \\
\hline $\begin{array}{l}\text { zastępca } \\
\text { rodzica }\end{array}$ & $\begin{array}{l}\text { Urządzenie mobilne jest dla rodzica ,zastępcą”, gdy } \\
\text { interakcję ja-dziecko-urządzenie dotykowe postrzega } \\
\text { jako okazje do wycofania się z kontaktu z dzieckiem, } \\
\text { możliwości chwilowego zwolnienia siebie z koniecz- } \\
\text { ności stałego kierowania uwagi na dziecko. Rodzic } \\
\text { pozostawia dziecko „pod opieką” urządzenia dotyko- } \\
\text { wego. Tym samym zwalnia siebie z konieczności peł- } \\
\text { nienia funkcji responsywnego opiekuna, reagowania } \\
\text { na sygnały dziecka. Dzięki temu zyskuje możliwość } \\
\text { np. wykonania obowiązków zawodowych, zajęcia się } \\
\text { drugim dzieckiem czy wykonania prac domowych. } \\
\text { Wycofanie to może dawać rodzicowi możliwość uzy- } \\
\text { skania tzw. chwili dla siebie, odpoczynku. }\end{array}$ & $\begin{array}{l}\text { „Chca niech oglaja i bawia } \\
\text { sie jednoczesnie a ja sobie } \\
\text { wtedy siade i spokojnie } \\
\text { kawy napije i ksiazke poczy- } \\
\text { tam a co tam... a inne mamy } \\
\text { niech wieszaja na mnie psy } \\
\text { i zaklinaja ze ja taka zła”. }\end{array}$ \\
\hline $\begin{array}{l}\text { regulator } \\
\text { emocji }\end{array}$ & $\begin{array}{l}\text { Urządzenie mobilne jest dla rodzica ,regulatorem } \\
\text { emocji”, gdy interakcję ja-dziecko-urządzenie do- } \\
\text { tykowe postrzega jako sposobność do zmniejszenia } \\
\text { poziomu pobudzenia emocjonalnego swojego czy też } \\
\text { dziecka. Stara się wycofać ze swojej roli w diadycznej } \\
\text { regulacji emocji dziecka poprzez doprowadzenie do } \\
\text { kontaktu dziecka z urządzeniem mobilnym. Czy też } \\
\text { wyregulować własne pobudzenie emocjonalne spowo- } \\
\text { dowane kontaktem z dzieckiem, poprzez przeniesienie } \\
\text { uwagi dziecka i/lub własnej na urządzenia mobilne. } \\
\text { Dotyczy to sytuacji, w których dziecko i/lub dorosły } \\
\text { doświadczają trudnych i silnych emocji. Dziecko ma- } \\
\text { nifestuje je poprzez płacz lub krzyk. }\end{array}$ & $\begin{array}{l}\text { „Gdy uszy puchną a nasze } \\
\text { nerwy trzeszczą ostrzegaw- } \\
\text { czo, jest coś, co w magicz- } \\
\text { ny sposób przywraca błogą } \\
\text { ciszę i uśmiech na twarzy } \\
\text { naszego pierworodnego. } \\
\text { Jest to (ciiii....) gra «Fruit } \\
\text { Ninja»”. }\end{array}$ \\
\hline
\end{tabular}


Niemal każda analizowana narracja zawierała w sobie kilka znaczeń nadanych urządzeniu dotykowemu, co naszym zdaniem świadczy o dużej roli, jaką odgrywają one w życiu rodzin z małymi dziećmi. Różnorodność wyodrębnionych w badaniu kategorii ukazuje rozległość oddziaływań urządzeń mobilnych na wszystkie sfery funkcjonowania dzieci w wieku 0-4 lat - fizjologiczną, emocjonalną, poznawczą i społeczną. Wyjaśnień możemy poszukiwać, odwołując się do specyfiki rozwoju dzieci w okresie wczesnego dzieciństwa, który jest niezwykle dynamiczny, wymaga od rodzica początkowo stałej dostępności i bliskości, następnie elastycznego dostosowania się do dążenia dziecka do autonomii i balansowania pomiędzy jego pragnieniami a rozsądnym stawianiem dziecku ograniczeń i wymagań, a także stawia opiekuna wobec konieczności radzenia sobie $\mathrm{z}$ nieuchronnymi i trudnymi okresami negatywizmu (Appelt, 2005; Białecka-Pikul, 2014; Czub, 2005a; Czub, 2005b; Schaffer, 2005).

Zauważamy także wagę uwarunkowań sytuacyjnych - współcześni rodzice, którzy potrzebują wsparcia w tak wymagającym okresie życia dziecka, a nie znajdują go w najbliższym otoczeniu społecznym, posiłkują się otoczeniem fizycznym:

„Fajnie się mówi spędzaj z dzieckiem czas, nie dawaj tabletów, nie puszczaj bajek, edukuj itd. Zwłaszcza jak mówią to Panowie. [...] Mając cały dom na głowie, wszystkie prozaiczne czynności jak sprzątanie, gotowanie, pranie, robienie zakupów i setki innych spraw na głowie i pracując na cały etat, w dodatku z dziećmi, które chodzą spać nie wcześniej niż o 21:30 [...] to przepraszam bardzo, ale poświęcanie maksymalnego czasu dzieciom i nie posiłkowanie się tabletem albo bajkami jest po prostu niemożliwe" (mama bliźniąt w wieku 36 miesięcy).

Nieco odmiennych spostrzeżeń dostarcza kategoria „zagrożenie” (Z), wypowiedzi rodziców, które zostały do niej zakwalifikowane, świadczą o izolacji lub znacznie ograniczonym dostępie dziecka do urządzeń dotykowych. Motywy determinujące takie zachowanie rodziców okazały się różnorodne, omówimy dwa naszym zdaniem znaczące dla dalszych badań w tym obszarze.

Pierwszym jest zjawisko nazwane przez nas falstartem cyfrowym. Odnosi się do sytuacji w której rodzic we wcześniejszych etapach życia dziecka umożliwił mu dostęp do nowych technologii, co w opinii jego lub specjalistów spowodowało niekorzystne skutki rozwojowe. Hipotetycznie izolacja, którą rodzic stosuje obecnie, może być zarówno przejawem wysokiej wrażliwości rodzicielskiej, jak i przejawem blokowania jej ekspresji pod wpływem lęku. W pierwszym przypadku rodzic po zachowaniu antycypującym zaobserwował niekorzystne sygnały płynące od dziecka - na przykład znaczne pobudzenie, ograniczenie eksploracji tylko do urządzenia mobilnego - i zdecydował się na jego korektę w formie wycofania zadania, co na obecnym etapie rozwoju dziecka jest dla niego korzystne. Natomiast w drugim lęk wywołany niepożądanymi skutkami spowodował u rodzica trwałe odsunięcie dziecka od nowych technologii. Pomimo upływu czasu, zmian rozwojowych i potencjalnej gotowości dziecka do podjęcia $\mathrm{z}$ nim tutoringu cyfrowego rodzic nie podejmuje zachowań antycypujących w tym obszarze w celu zdiagnozowania możliwości dziecka. Wspomnianą sytuację opisuje fragment wypowiedzi:

„Pierwsze kontakty córki z tego typu sprzętami odbyły się około 6-7 miesiąca życia. Tak, tak, dobrze czytacie, nie pomyliłam się. Na rozdrażnienie - Elmo's song. Na znudzenie - Mahna mahna. Dla rozrywki - Kaczuszki. Iphone nie krzywi zębów, nie rozleniwia języka i nie jest tak uzależniający jak smoczek. To próby idealizacji naszych czynów. [...] Problemy się zaczęły przed ukończeniem 2 r.ż. córka zmieniła się nie do poznania. [...] Podjęliśmy decyzję, że nie będziemy jej puszczać bajek oraz ograniczyć oglądanie telewizji do minimum. Problem zniknął. [...] Wiem, uznacie mnie za kosmitkę. Zdaję sobie $\mathrm{z}$ tego sprawę, że w dobie komputeryzacji dziecko bez dostępu do tableta, smartfonu i telewizji może wydawać się dziwne. Argumenty, że trzeba od małego uczyć obsługi urządzeń elektronicznych, do mnie nie przemawiają" (mama dziewczynki w wieku 36 miesięcy). 
Tabela 2. Emocje rodziców wobec interakcji ja-dziecko-urządzenie dotykowe lub wobec antycypacji interakcji dziecko-urządzenie - fragmenty narracji

\begin{tabular}{|c|c|}
\hline Emocje & Fragment narracji \\
\hline $\begin{array}{l}\text { wdzięczność wo- } \\
\text { bec urządzenia/ } \\
\text { ulga }\end{array}$ & $\begin{array}{l}\text { „Tablet ratuje mi życie, gdy mam zapierdziel w pracy i nie mogę sobie usiąść } \\
\text { z synem na dywanie i pobawić się klockami. Młodzian bierze sobie tablet, uru- } \\
\text { chamia, co tam chce i układa puzzle, rysuje, czy co tam mu się akurat umyśli” } \\
\text { (Agnieszka) } \\
\text { „ale wiem jedno — U NAS MEGA SĄ POTRZEBNE!!! Najlepsze podczas } \\
\text { dłuższej podróży, najlepsze gdy robię obiad, bez nich nie wiem czy miałabym } \\
\text { czas usiąść na toalecie” (WISIA) } \\
\text { „Kocham narzędzia Szatana. Uwielbiam je. Często myślę o Matkach parędziesiąt } \\
\text { lat temu i ciarki mnie przechodzą - jak one dawały radę?! Bez TV? Bez netu? Bez } \\
\text { interaktywnych aplikacji???” }\end{array}$ \\
\hline $\begin{array}{l}\text { lęk przed uzależ- } \\
\text { nieniem dziecka } \\
\text { od urządzenia }\end{array}$ & $\begin{array}{l}\text { „Mam fisia na punkcie tematu dziecko a ekran bo znam kilka przypadków do- } \\
\text { rosłych już ludzi, którzy są od komputera/komórki ciężko uzależnieni i przez } \\
\text { to trudno im funkcjonować w realu. Dlatego boję się o moją dwulatkę i tak, jak } \\
\text { dziewczyny piszą: sporadycznie, jako ostatnia deska ratunku [...]” (missgiggles) }\end{array}$ \\
\hline $\begin{array}{l}\text { wstyd, poczucie } \\
\text { winy }\end{array}$ & $\begin{array}{l}\text { „Le, moja najgorsza porażka, bajki z tabletu :/ dziecko przy nich usypia na popo- } \\
\text { łudniową drzemkę, potem się budzi i ogląda z piętnaście minut na otrzepanie się, } \\
\text { ja w tym czasie grzeję obiad. [...] No, jak mówię, bajki to moja osobista porażka, } \\
\text { okrutnie się potrafi wciagnąć. jest zdecydowanie za mała, niestety” (nene) }\end{array}$ \\
\hline $\begin{array}{l}\text { gniew/ oburze- } \\
\text { nie wobec osób } \\
\text { podejmujących } \\
\text { odmienne zacho- } \\
\text { wania w oma- } \\
\text { wianych interak- } \\
\text { cjach }\end{array}$ & $\begin{array}{l}\text { „Pisze Pani o tych wszystkich elektronicznych zabawkach jak o największej } \\
\text { krzywdzie dla dziecka, a oskarżycielski ton Pani wypowiedzi daje jasno do zro- } \\
\text { zumienia, że rodzice którzy pozwalają swoim dzieciakom na tego typu zabawę } \\
\text { są leniwi i źli... Moja córka ma dwa lata: obsługuje iPhone lepiej niż ja, włącza } \\
\text { sobie sama ulubione bajki. Co z tego ma? Zna } 9 \text { kolorów po angielsku, liczy do } 10 \\
\text { również po angielsku, po polsku rownież liczy tyle ze do 8, zna alfabet (po polsku } \\
\text { i angielsku). I proszę sobie wyobrazić, że potrafi rysować o malować, na podwór- } \\
\text { ku spędza mnóstwo czasu, pięknie dzieli sie zabawkami ze swoją malutką siostrą } \\
\text { a teraz właśnie sama zjada rosół...” (Ala) } \\
\text { „Znam dzieci które pół dnia oglądają bajki, pół kolejnego dnia grają na tabletach } \\
\text { i komórkach. Obsługują komputer i odtwarzacz dvd. Nie umieją za to same pode- } \\
\text { trzeć sobie pupy, nie trzymają prawidłowo kredek. Nie są w stanie zjeść samo- } \\
\text { dzielnie zupy, zawiązać sznurówek, nie widziały na żywo krowy a mleko według } \\
\text { nich pochodzi z kartonu... Ja dokonuję innych wyborów [...]” }\end{array}$ \\
\hline $\begin{array}{l}\text { ambiwalencja } \\
\text { wobec urządzeń } \\
\text { dotykowych }\end{array}$ & $\begin{array}{l}\text { „Ostatnio przyłapałam się, że moje dziecko nie potrafi zjeść bez bajki na table- } \\
\text { cie.:/ Czy jestem tu sama, jeśli chodzi o taki urozmaicony obiad, czy jest was } \\
\text { więcej? [...] O ile jazda samochodem mi teraz odpowiada, ponieważ zawsze } \\
\text { był piekielny wrzask z powodu bezczynnego siedzenia, to już jedzenie z table- } \\
\text { tem mi bardzo przeszkadza! Rozumiem, że świat niestety idzie z postępem i jest } \\
\text { to nieuniknione, że dziecko, które widzi matkę i ojca ciągle siedzących w takich } \\
\text { sprzętach ma postępować inaczej. [...] Zdaję sobie mocno sprawę, że dzieci, któ- } \\
\text { re korzystają z takich wynalazków, a nie ukończyły jeszcze } 3 \text { roku życia mogą } \\
\text { w przyszłości mieć problemy chociażby w interakcji z rówieśnikami. [...] Sta- } \\
\text { ram się jak moge, aby takie sprzęty Lilianka miała w posiadaniu jak najrzadziej, } \\
\text { ale nie będę całkowicie jej tego zabraniać. Świat idzie z postępem i kto wie, czy } \\
\text { za kilka lat będą potrzebne dziecku książki w szkole, a zamiast tego komputer” } \\
\text { (Magda) }\end{array}$ \\
\hline
\end{tabular}


Kolejnym motywem izolacji była wyraźna identyfikacja rodzica z pokoleniem cyfrowych imigrantów, co w narracjach przejawiało się wypowiedziami za wzór wychowania stawiającymi własne dzieciństwo lub czasy, gdy dzieci nie miały dostępu do nowych technologii. Na przykład:

„Istniał przecież kiedyś świat bez komputerów, pamiętam siebie jako takie «dzikie-dziecko» biegające po dworze z kijkiem, urządzające tajne bazy na drzewach, za garażami, jak wtedy działała moja i innych dzieci z podwórka wyobraźnia. Teraz dzieciaki siedzą wpatrzone w ekrany, wszędzie «szkalna pogoda» i trochę smutno mi się robi na duszy..." (mama chłopca w wieku 27 miesięcy, pisownia oryginalna).

W narracjach świadczących o wspomnianej identyfikacji wyróżniały się także: duma z własnych kompetencji w organizowaniu dziecku czasu „bez ekranów” (ang. unplugged): „My nie mamy w domu telewizora, tableta, ipoda ani ipada itp. Ten artykul uswiadomil mi, ze dobrze robimy. Moj pierwszy synek mial $17 \mathrm{~m}$-cy jak poznal wszystkie litery, zaczal sie ich uczyc jak mial rok. Teraz ma 3 lata, uczy sie 3 jezykow jednoczesnie, wie co to szescian, stozek, wulkan, saturn, zna prawie wszystkie flagi krajow... itp itd wiec mysle, ze wychowanie $z$ dala od technologii moze wyjsc dzieciom na dobre" (mama chłopca w wieku 36 miesięcy; pisownia oryginalna); oraz powoływanie się na opinie specjalistów o niekorzystnym wpływie nowych technologii na rozwój dziecka.

Ponadto $\mathrm{z}$ analizowanego materiału wyodrębniłyśmy pięć ustosunkowań emocjonalnych rodziców wobec opisywanych interakcji, które zostały przedstawione w tabeli 2 .

Dla niektórych rodziców tablety i/lub smartfony stają się nieocenioną pomocą w opiece nad dzieckiem i są wykorzystywane do osiaggnięcia wielu celów, o czym świadczy wypowiedź:

„Moja corka od zawsze inhaluje sie przy bajkach (przy zapaleniach oskrzeli bywalo i 5 inhalacji dziennie), przed ukonczeniem 2 lat zaczela ogladanie bajek na dobranoc (poczatkowo to byly 2 Pepki, potem sie wydluzylo), jak miala 3 lata i na swiat przyszedl mlodszy brat - doszly gry na tablecie/smartfonie i bajki w ciagu dnia zeby dostarczyc rozrywki/zajac czyms, szczegolnie obficie serwowane podczas chorob (a byl to pierwszy rok przedszkola i cykle chorobowe wygladaly 3 tyg choroby/3 dni zdrowia). Przerabialismy bajki/gry jako przekupstwo aby polknela antybiotyk lub np ubrala sie rano i wyszla do przedszkola, a w ciezkie dni byly i pelnometrazowe kreskowki (Kopciuszek, Dumbo, Kraina Lodu) lub dlugie sesje pielegnacji zwierzat/dzieci czy przyrzadzania wirtualnych deserow, uprawy cyfrowej roli zeby byla godzina spokoju i zebym nie zwariowala. W tych najgorszych okresach mialam spore wyrzuty sumienia, ze mam dziecko nie tylko zaniedbane, ale jeszcze uzaleznione od tableta..." (mama dzieci w wieku 48 i 12 miesięcy, pisownia oryginalna).

Cytowany fragment jest jednocześnie ilustracją kolejnego wniosku. Dla wielu rodziców cel, jaki chcą osiągnąć, oraz motywowane nimi zachowanie, które podejmują w interakcjach ja-dziecko-urządzenie dotykowe, lub jedynie antycypacja interakcji dziecko-urządzenie jest źródłem silnych emocji.

\section{DYSKUSJA}

\section{Miejsce znaczeń nadawanych urządzeniu mobilnemu w interakcji rodzic-dziecko- urządzenie dotykowe w modelu wrażliwego nauczania}

Pomimo ograniczeń naszego badania jego wyniki przybliżyły nas do zrozumienia miejsca niektórych spośród wyodrębnionych znaczeń w utworzonym modelu teoretycznym wrażliwego nauczania. Dalsze rozważania mają charakter hipotez dotyczących związku znaczeń $\mathrm{z}$ poziomem wrażliwości nauczania $\mathrm{w}$ interakcji rodzic-dziecko-urządzenie dotykowe.

Wysuwamy przypuszczenie, że znaczenie „zastępca rodzica” (ZR) nadane urządzeniu dotykowemu implikuje ignorowanie sygnałów wysyłanych przez dziecko, czym uniemożliwia zaistnienie wrażliwego nauczania. Bazowy komponent wrażliwości rodzicielskiej - świadome ukierunkowanie na sygnały płynące od dziecka - zawiera w sobie dwa aspekty: dostępność i niski próg reakcji opiekuna na sygnały dziecka (Ainsworth i in., 1978). W narracjach zakla- 
syfikowanych do kategorii „zastępca rodzica” (ZR) dorosły wycofuje się z interakcji, a cel jego działań w naturze swojej zakłada niedostępność rodzica i wysoki próg jego reakcji na sygnały dziecka. Interakcje, zainicjowane przez rodzica pod wpływem omawianego znaczenia, pozbawione są wrażliwości rodzicielskiej, według modelu teoretycznego warunku koniecznego do wystąpienia wrażliwości w obszarze odziaływań edukacyjnych.

Według przeprowadzonej analizy kategorie „rozrywka” (R) oraz „edukator” (E) mogą zarówno determinować wrażliwą odpowiedź na potrzeby eksploracyjne dziecka, jak i współwystępować $\mathrm{z}$ intruzywnym stymulowaniem jego zachowań eksploracyjnych (Czub, 2005b).

Ciekawych hipotez dostarcza kategoria ,zagrożenie" (Z), która przypuszczalnie może współwystępować z brakiem wysokiej wrażliwości rodzicielskiej, jak i być jej przejawem - te dwie potencjalne zależności omówiono powyżej.

Hipotetycznie zależność znaczenia i wrażliwości rodzicielskiej ma postać dwukierunkową. Niski poziom wrażliwości rodzicielskiej może powodować tendencję rodzica do nadawania znaczeń blokujących wystąpienie wrażliwego nauczania. Same zaś znaczenia mogą wpływać na poziom ekspresji wrażliwości rodzicielskiej. Nawet opiekun wysoko dostępny i uważny na sygnały dziecka może je mylnie zinterpretować (Ainsworth i in., 1978). Myślimy tu o sytuacji, w której percepcja opiekuna zostanie zniekształcona procesem nadania znaczenia urządzeniu, jako obiektowi interakcji - a określony w tym procesie cel rodzica zdecyduje o kształcie interakcji.

Istotne pozostaje także ustalenie, $\mathrm{z}$ którym typem użytkownika nowych technologii identyfikuje się rodzic. Jeśli z cyfrowymi tubylcami, E. Helsper i R. Eynon zdefiniowały go jako multitaskera, ze stałym dostępem do wielu nowoczesnych urządzeń, pewnego siebie w kontakcie z nowymi technologiami, preferującego internet jako pierwsze źródło informacji, i używającego go zarówno do pracy (nauki), jak i rozrywki (2009, s. 5). Przypuszczalnie właśnie ten typ rodziców chętniej i szybciej w porównaniu z cyfrowymi imigrantami wprowadzi swoje dziecko w świat urządzeń mobilnych.

\section{PODSUMOWANIE}

Podsumowując, można stwierdzić, że przeprowadzone badanie eksploracyjne uprawnia do sformułowania trzech głównych wniosków:

1. W badanej próbie rodziców małych dzieci odkryto różnorodność znaczeń nadawanych urządzeniom mobilnym $w$ interakcji ja-dziecko-urządzenie dotykowe. Dla większości tablety czy smartfony w interakcjach z dzieckiem występują w kilku znaczeniach, a za pomocą tabletu/smartfona rodzice próbują osiagnnąć różnorodne cele, np. odwrócić uwagę dziecka od nieprzyjemnej czynności, dostarczyć dziecku rozrywki czy zapewnić sobie przerwę w opiece nad nim. Świadczy to o istotnej roli, jaką wskazane urządzenia pełnią w życiu rodzin z małymi dziećmi.

2. Wprowadzanie urządzeń mobilnych do interakcji z dzieckiem lub jedynie antycypacja takiej interakcji wywołują w rodzicach silne emocje. W omawianej próbie wykryto pięć ustosunkowań emocjonalnych, są to: wdzięczność wobec urządzenia, lęk przed uzależnieniem dziecka od urządzenia, wstyd i poczucie winy, gniew, ambiwalencja.

3. Zakładamy hipotetycznie, że korzystne dla rozwoju małego dziecka są interakcje, w których po stronie rodzica wystąi wrażliwe nauczanie - tutoring cyfrowy wsparty wrażliwością rodzicielską. Niezbędne w omawianych interakcjach wydaje się wyczulenie rodzica na sygnalizację potrzeb eksploracji i przywiązania przez dziecko i właściwa odpowiedź w ramach uruchomionego systemu.

Wnioski te wskazują na zasadność i potrzebę dalszych badań w przedmiotowym obszarze. 


\section{PRZYPISY}

${ }^{1} \mathrm{~W}$ opracowaniu zamiennie używane są sformułowania urządzenie dotykowe oraz urządzenie mobilne na określenie tabletów i smartfonów.

${ }^{2}$ L.S. Wygotski (2006) wskazywał, że: „dziecko wchodzi w stosunki z sytuacją nie bezpośrednio, ale za pośrednictwem drugiej osoby. [...] Cała historia rozwoju psychicznego dziecka poucza nas, że już od pierwszych dni tego rozwoju przystosowanie dziecka do środowiska jest osiagane środkami społecznymi, za pośrednictwem otaczających je ludzi. Droga od przedmiotu do dziecka i od dziecka do przedmiotu prowadzi poprzez drugiego człowieka" (Wygotski, 2006, s. 35-36).

${ }^{3}$ P. S. Klein (1994) za jedno z pięciu kryteriów decydujących o wystąpieniu upośrednionego uczenia się uznała upośrednianie znaczenia (ang. mediated meaning) i zdefiniowała je jako ,zachowanie dorosłego, który wyraża słowną lub niewerbalną ocenę bądź uczucie w stosunku do przedmiotów, zwierząt lub pojęć i wartości" (Klein, 1994, s. 192).

${ }^{4} \mathrm{~W}$ kontekście problematyki podjętej w opracowaniu prawidłowości wrażliwego nauczania odnosimy do rodzica, jednakże analogicznie dotyczą one także nauczyciela czy rówieśnika, czyli każdej osoby przyjmującej w tym specyficznym układzie edukacyjnym rolę osoby nauczającej.

${ }^{5}$ Emilia Soroko (2007) wskazuje, że znaczenie możemy zdefiniować za Podręcznym stownikiem terminów literackich jako zdolność słów, zdań, wypowiedzi do powiadamiano o czymś, co znajduje się poza nimi, w sferze przedmiotów, w sferze psychicznej lub pojęciowej (Soroko, 2007, s. 202).

${ }^{6}$ Za Marią Straś-Romanowską, Bogną Bartosz i Magdaleną Żurko (2010) przyjmujemy, że narracyjność wypowiedzi wyrażać będzie się w jej podmiotowości (relacjonowanie zdarzeń z pozycji bohatera opowieści). Tym samym narracja osobista daje psychologom możliwość wnioskowania m.in. o przeżyciach czy sposobach interpretowania i wartościowania zdarzeń przez daną osobę (Straś-Romanowska, Bartosz, Żurko, 2010, s. 23). Z kolei Emilia Soroko (2010) proponuje używanie terminu ,autonarracja” w odniesieniu do opowieści będącej efektem relacjonowania doświadczeń, w które opowiadający jest zaangażowany osobiście. Na potrzeby niniejszego opracowania przyjmujemy powyższe kryterium jako decydujące o narracyjności wypowiedzi.

${ }^{7}$ Sędziowie kompetentni: kobieta 32 lata, mężczyzna 30 lat, oboje wykształcenie wyższe, w tym jedno z wykształceniem psychologicznym. Osoby będące rodzicami dzieci w wieku $0-5$ lat, korzystające na co dzień z nowych technologii, tym samym znające realia funkcjonowania rodziny z małymi dziećmi w obecnych warunkach społeczno-kulturowych.

${ }^{8}$ Jak podają Krzysztof Krejtz i Izabella Krejtz (2005b) za Lombardem i wsp. (2004), „można przyjąć, iż zmienna została rzetelnie stworzona, jeśli wartość liberalnego wskaźnika przekracza 0,8 , a konserwatywnego 0,5" (Lombard i wsp., 2005; za: Krejtz, Krejtz, 2005, s. 248). Współczynnik pi ( $\pi$ ) Scotta jest zaliczany przez autorów do konserwatywnych, przyjmuje wartość od -1 do 1, gdzie -1 oznacza całkowity brak zgodności, a 1 całkowitą zgodność kodowania sędziów.

\section{BIBLIOGRAFIA}

Ainsworth M.D.S., Bell S.M. (1970), Attachment, exploration, and separation: Illustrated by the behavior of one-year-olds in a strange situation. Child Development, 41, 49-67.

Ainsworth M.D.S., Blehar M.C., Waters E., Wall S. (1978), Patterns of Attachment: A psychological study of the strange situation. Hillsdale, NJ: Lawrance Erlbaum.

Appelt K. (2005), Wiek poniemowlęcy. Jak rozpoznać potencjał dziecka? W: A.I. Brzezińska (red.), Psychologiczne portrety człowieka. Praktyczna psychologia rozwojowa (95-130). Gdańsk: Gdańskie Wydawnictwo Psychologiczne.

Bąk A. (2015), Korzystanie z urzadzeń mobilnych przez małe dzieci w Polsce. Wyniki badania ilościowego. Warszawa: Fundacja Dzieci Niczyje.

Białecka-Pikul M. (2014), Wczesne dzieciństwo. W: J. Trempała (red.), Psychologia rozwoju człowieka (172-201). Warszawa: PWN.

Blumer H. (1969), Symbolic interactionism. Perspective and method. Englewood Cliffs, New Jersey: Prentice-Hall. 
Bowlby J. (2007), Przywiqzanie. Warszawa: PWN.

Bradley R.H., Burchinal M., Casey P.H. (2001), Early intervention: the moderatig role of the home environment. Applied Developmental Science, 5, 1, 2-8.

Brown A.L., Ferrara R. (1994), Poznawanie stref najbliższego rozwoju. W: A. Brzezińska, G. Lutomski (red.), Dziecko w świecie ludzi i przedmiotów (217-254). Poznań: Zysk i S-ka.

Chaudron S. (2015), Young Children (0-8) and digital technology: A qualitative exploratory study across seven countries. Italy: Jonint Research Centre. Publications Office of the European Union.

Czub M. (2005a), Wiek niemowlęcy. Jak rozpoznać potencjał dziecka? W: A.I. Brzezińska (red.), Psychologiczne portrety człowieka. Praktyczna psychologia rozwojowa (41-66). Gdańsk: Gdańskie Wydawnictwo Psychologiczne.

Czub T. (2005b), Wiek niemowlęcy. Jak rozpoznać ryzyko? I jak pomagać? W: A.I. Brzezińska (red.), Psychologiczne portrety czlowieka. Praktyczna psychologia rozwojowa (67-94). Gdańsk: Gdańskie Wydawnictwo Psychologiczne.

Filipiak E. (2011), Z Wygotskim i Brunerem w tle: Stownik pojęć kluczowych. Bydgoszcz: Wydawnictwo Uniwersytetu Kazimierza Wielkiego.

Glaser B.G., Strauss A.L. (2009), Odkrywanie teorii ugruntowanej: strategie badania jakościowego. Kraków: Zakład Wydawniczy Nomos.

Grossmann K.E., Grossmann K., Waters E. (eds.) (2005), Attachment from infancy to adulthood: The major longitudinal studies. New York: Guilford Press.

Grossmann K.E., Bretherton I., Waters E., Grossmann K. (eds.) (2013), Maternal sensitivity: Observational studies honoring Mary Ainsworth's $100^{\text {th }}$ year. Special Issue. Attachment and Human Development, 15.

Heider F. (1958), The psychology of interpersonal relations. Hoboken: John Wiley \& Sons Inc.

Helsper E., Eynon R. (2009), Digital natives: Where is the evidence? British Educational Research Journal, $35,1-18$.

Hewitt J.P. (1979), Self and society: a symbolic interactionist social psychology. Boston: Allyn and Bacon.

Hornowska E., Brzezińska A.I., Appelt K., Kaliszewska-Czeremska K. (red.) (2014), Rola środowiska w rozwoju matego dziecka - metody badania. Warszawa: Wydawnictwo Naukowe Scholar.

Kaja B.M. (2010), Psychologia wspomagania rozwoju człowieka: zrozumieć świat życia człowieka. Sopot: Gdańskie Wydawnictwo Psychologiczne.

Klein P.S. (1994), Całościowa ocena i interwencja w okresie niemowlęctwa i wczesnego dzieciństwa. W: A. Brzezińska, G. Lutomski (red.), Dziecko w świecie ludzi i przedmiotów (189-216). Poznań: Zysk i S-ka.

Krejtz K., Krejtz I. (2005a), Metody analizy treści - teoria i praktyka badawcza. W: K. Stemplewska-Żakowicz, K. Krejtz (red.), Wywiad psychologiczny. Wywiad jako postępowanie badawcze (129-149). Warszawa: Pracownia Testów Psychologicznych Polskiego Towarzystwa Psychologicznego.

Krejtz K., Krejtz I. (2005b), Rzetelność w analizie treści. W: K. Stemplewska-Żakowicz, K. Krejtz (red.), Wywiad psychologiczny. Wywiad jako postępowanie badawcze (217-230). Warszawa: Pracownia Testów Psychologicznych Polskiego Towarzystwa Psychologicznego.

Mead G.H. (1975), Umyst, osobowość i społeczeństwo. Warszawa: PWN.

Miotk-Mrozowska M. (2009), Komunikacja interpersonalna w internecie. Bydgoszcz: Wydawnictwo Uniwersytetu Kazimierza Wielkiego.

Miotk-Mrozowska, M. (2011), Współpraca szkoły z rodzicami ucznia. W: S. Kowalik (red.), Psychologia ucznia i nauczyciela. Podręcznik akademicki (220-249). Warszawa: PWN.

Ólafsson K., Livingstone S., Haddon L. (2013), Children's use of online technologies in europe: a review of the european evidence database. London: School of Economics and Political Science and EU Kids Online.

Prensky M. (2001), Digital natives, digital immigrants. On the Horizon. Brandford: MCB University Press, $9,5,1-5$.

Radesky J.S., Schumacher J., Zuckerman B. (2015), Mobile and interactive media use by young children: the good, the bad, and the unknown. Pediatrics, 135, 1, 1-3.

Rheingold H L., Adams J. L. (1980), The significance of speech to newborns. Developmental Psychology, $16,397-403$. 
Ryan R.M., Deci E.L. (2000).The darker and brighter sides of human existence: Basic psychological needs as a unifying concept. Psychological Inquiry, 11, 319-338.

Schaffer H.R. (1994a), Społeczny kontekst rozwoju psychobiologicznego. W: A. Brzezińska, G. Lutomski (red.) Dziecko w świecie ludzi i przedmiotów (72-95). Poznań: Zysk i S-ka.

Schaffer H.R. (1994b), Wczesny rozwój społeczny. W: A. Brzezińska, G. Lutomski (red.), Dziecko w świecie ludzi i przedmiotów (96-124). Poznań: Zysk i S-ka.

Schaffer H.R. (1994c), Wzajemność kontroli we wczesnym dzieciństwie. W: A. Brzezińska, G. Lutomski (red.), Dziecko w świecie ludzi i przedmiotów (125-149). Poznań: Zysk i S-ka.

Schaffer H.R. (1994d), Epizody wspólnego zaangażowania jako kontekst rozwoju poznawczego. W: A. Brzezińska, G. Lutomski (red.), Dziecko w świecie ludzi i przedmiotów (151-188). Poznań: Zysk i S-ka.

Schaffer H.R. (2005), Dziecko jako praktykant: Wygotskiego społeczno-poznawcza teoria rozwoju. W: H.R. Schaffer (red.), Psychologia dziecka (216-244). Warszawa: PWN.

Schore A. (2002), The neurobiology of attachment and early personality organisation. Journal of Prenatal \& Perinatal Psychology \& Health, 16, 3, 249-263.

Shotter J. (1994), Psychologia Wygotskiego: Wspólna aktywność w strefie rozwoju. W: A. Brzezińska, G. Lutomski (red.), Dziecko w świecie ludzi i przedmiotów (13-44). Poznań: Zysk i S-ka.

Siuda P., Sunża G.D. (red.) (2012), Dzieci Sieci-kompetencje komunikacyjne najmłodszych. Raport z badań. Gdańsk: Instytut Kultury Miejskiej.

Smykowski B. (2003), Porządek rozwoju funkcji psychicznych a dynamika form działalności dziecka. Edukacja, 1, 81, 19-32.

Snow C.E. (1977), The development of conversation between mothers and babies. Journal of Child Development, 50, 989-998.

Soroko E. (2007), Poziom autonarracyjności wypowiedzi i użyteczność wybranych sposobów ich generowania. Niepublikowana praca doktorska. Instytut Psychologii, Uniwersytet im. Adama Mickiewicza w Poznaniu.

Soroko E. (2010), Określanie wad i zalet metod generowania autonarracji. W: M. Straś-Romanowska, B. Bartosz, M. Żurko (red.), Psychologia matych i wielkich narracji (101-128). Warszawa: Eneteia.

Staksrud E., Livingstone S., Haddon L., Ólafsson K. (2009), What do we know about children's use of online technologies?: a report on data availability and research gaps in Europe [2 $\left.{ }^{\text {nd }} \mathrm{ed}.\right]$. EU Kids Online, London, UK.

Straś-Romanowska M., Bartosz B., Żurko M. (2010), Narracja jako opowieść indywidualna i jako tekst kultury. W: M. Straś-Romanowska, B. Bartosz, M. Żurko (red.), Psychologia małych $i$ wielkich narracji (13-21). Warszawa: Eneteia.

Wood D. (1995), Społeczne interakcje jako tutoring. W: A.I. Brzezinska, G. Lutomski, B. Smykowski (red.), Dziecko wśród rówieśników i dorostych (214-235). Poznań: Zysk i S-ka.

Wood D. (2006), Jak dzieci uczq się i myślq. Społeczne konteksty rozwoju poznawczego. Kraków: Wydawnictwo Uniwersytetu Jagiellońskiego.

Wygotski L.S. (1971), Wybrane prace psychologiczne. Warszawa: PWN.

Wygotski L.S. (2002a), Problem wieku rozwojowego. W: A. Brzezińska, M. Marchow (red.), L.S. Wygotski, Wybrane prace psychologiczne II: dzieciństwo i dorastanie (61-90). Poznań: Zysk i S-ka.

Wygotski L.S. (2002b), Wczesne dzieciństwo. W: L.S. Wygotski, Wybrane prace psychologiczne II: dzieciństwo i dorastanie (91-129). Poznań: Zysk i S-ka.

Wygotski L.S. (2006), Narzędzie i znak w rozwoju dziecka. Warszawa: PWN. 


\section{ZALĄCZNIK 1}

\section{Obszar pozyskiwania źródel archiwalnych}

1) Internetowe grupy dyskusyjne (fora internetowe):

1. http://forum.gazeta.pl/forum/w,566, 161087760,161087760,daje_choc_nie_powinnam_html.

2. http://dziecko-info.rodzice.pl/forum/nasze-dzieci/wiek-przedszkolny/126552-czy-tablet-szkodzi-3-latkowi.

3. http://www.maluchy.pl/forum/index.php?showtopic=97193\&hl=tablet.

4. http://dzidziusiowo.pl/forum/topic/127, tablet.

5. http://f.kafeteria.pl/temat/f10/tablet-dla-dziecka-co-myslice-p_5779115.

6. http://www.benc.pl/grupy/forum/149/watek/2594282/3 latek $\overline{\mathrm{i}}$ tablet_czy to nie przesada.

7. http://forum.gazeta.pl/forum/w,566,161592034,161592034,Tablety_smartfony_itp.html.

2) Blogi rodzicielskie lub dotyczące nowych technologii:

1. http://dziecinneproblemytaty.blogspot.com/2015/11/czy-kupic-dziecku-tablet.html.

2. http://www.krzywaprosta.pl/2015/08/30/dziecko-wersja-cyfrowa-czy-analogowa/.

3. http://www.szczesliva.pl/czy-tylko-wyrodne-matki-kupuja-dziecku-tablet/.

4. http://www.tatawpracy.pl/czy-tablet-i-smartfon-musi-uwsteczniac-rozwoj-dziecka/.

5. http://www.folkmyself.pl/rodzina/matka-smartfon-ojciec-tablet-a-dziecko-nie-umie-wiazac-sznurowek/.

6. http://www.lefti.pl/dzieci-w-dobie-elektroniki/.

7. http://www.juliarozumek.pl/o-nie-nie/.

8. http://www.matkaniewariatka.pl/tablet-dla-dziecka-tak-czy-nie/.

9. http://blogrodzinny.blog.pl/2015/01/13/tablet-laptop-smartfon-czyli-zabawki-xxi-wieku/.

10. http://www.nebule.pl/co-mnie-laczy-ze-stevem-jobsem/.

11. http://rodzinawpraktyce.pl/dzieci-sa-analogowe/.

12. http://zuziulowy.blogspot.com/2014/05/tablet-dla-zuzia.html.

13. https://mam-smyka.pl/2015/11/06/pokolenie-internetu/.

14. https://ogrodnikumyslu.wordpress.com/2015/02/27/dac-dziecku-tablet-to-tak-jak-zabetonowac-mu-nogi-i-kazac-plywac/.

15. http://lalunaloca.blogspot.co.uk/2014/12/dlaczego-pozwalam-dziecku-bawic-sie.html.

16. http://dzieciowo.pl/2015/08/dzieci-i-tablety-niebezpieczne-zwiazki.html.

17. http://maminkowo.blog.onet.pl/2013/09/27/przedszkolak-z-tabletem/.

18. http://geektata.pl/cola-tabletu/.

19. http://www.klocekikredka.com/mamo-odpal-jutuba/.

20. http://hakierka.pl/2015/07/19/programowanie-dla-dzieci/.

21. http://mumandthecity.pl/gadzety-zyciu-kobiety-dziecka/.

22. http://dla-nich.blogspot.com/2014/03/o-obserwacjach-na-placu-zabaw.html.

23. http://bappki.pl/dziecko-i-tablet/.

24. http://www.dookolanas.pl/lifestyle/prawdziwe-zycie-vs-zycie-w-sieci/.

25. http://bestdamnmomever.blogspot.com/2015/10/jak-technologia-niszczy-dzieci.html.

26. http://aktywnytata.blogspot.com/2015/07/dzieci-nie-moga-sie-rozwijac-bez-tabletu.html.

27. http://madagene.pl/2016/03/nowoczesne-sprzety-czy-potrzebne-dzieciom/. 


\section{ZALĄCZNIK 2}

KLUCZ KODOWY / Znaczenia nadawane przez rodziców urządzeniu mobilnemu w interakcji ja-dziecko-urządzenie dotykowe

Oto pozycje kategorii. Proszę, przeczytaj każdą z wypowiedzi i określ, do której z kategorii Twoim zdaniem należy (jednej lub kilku). A może jest tak, że dana pozycja odzwierciedla inną niewyszczególnioną treść (kategorię)? Proszę, skorzystaj wtedy z kodu dla kategorii ,inne”, a w polu „uwagi” w arkuszu kodowania wpisz sugerowane twoim zdaniem znaczenie. Może intuicyjnie odczuwasz, że wypowiedź powinna zostać zaklasyfikowana do danej kategorii, choć nie spełnia koniecznych warunków? Proszę, oznacz to w uwagach, stawiając * przy symbolu kategorii, np. [RB]*.

\section{Instrukcja kodowania:}

1. Przeczytaj uważnie wypowiedź. Wszystkie to wypowiedzi rodziców dzieci w okresie wczesnego dzieciństwa (0-48 miesięcy), które dotyczą sytuacji rodzic-dziecko-urządzenia dotykowe (tablet, smartfon). Przyjmij założenie, że osoba wypowiadająca się ujawnia nie tylko treść własnych, bezpośrednich, codziennych doświadczeń, ale odsłania znaczenia i sens, które przypisała opisywanej sytuacji. Staraj się odszukać jawne i ukryte znaczenia.

2. Do danej kategorii zakwalifikuj wypowiedź, która spełnia poniższe warunki:

(1) stwierdzasz, że rodzic kształtuje sytuację ja-dziecko-urządzenie dotykowe we wskazanym celu - wskaźnik (A)

(2) stwierdzasz wystąpienie jednego lub więcej ze wskaźników z grupy (B) i/lub (C):

(B) występuje co najmniej jeden z wymienionych czynników podmiotowych (rodzic) $\mathrm{i} / \mathrm{lub}$

(C) udostępnienie urządzenia dotykowego ma miejsce w co najmniej jednej z wymienionych sytuacji uwaga: dla kategorii [Z] warunek (C) brzmi:

izolowanie od urządzenia dotykowego jest skutkiem co najmniej jednej z wymienionych sytuacji

pamiętaj $\rightarrow$ konieczne stwierdzenie występowania (A) oraz jednego z (B) lub (C)

3. Wpisz kod kategorii w odpowiedniej rubryce („kod”).

4. W polu uwagi dla każdego zbioru wskaźników(A), (B) i (C) oznacz ich występowanie (,,+”) lub stwierdzony brak danych wskaźników (,,-”). W przypadku (B) i (C) wpisz nazwy wskaźników lub numer wskaźników, których obecność stwierdzasz.

Przykład kodowania całej wypowiedzi:

\begin{tabular}{|c|c|c|}
\hline Całość wypowiedzi & Kod & Uwagi \\
\hline $\begin{array}{l}\text { Powiem szczerze, że miałam pewnie opory na początku z zapoznawa- } \\
\text { niem córki z ,jutubem”, ale już mi pszeszło, po tym jak moja 1,5 rocz- } \\
\text { na córka wita się mówiąc „haj” i żegna mówiąc „,baj” :). } \\
\text { Kiedy musiała na usg serca leżec spokojnie, pół godzinne badanie } \\
\text { oglądała ulice sezamkową na komórce. } \\
\text { Ogląda ją tylko po angielsku a ostatnio i sezamkową naukę hiszpań- } \\
\text { skiego chce żeby jej włączyc:) Cóż poradzę :) } \\
\text { Czytamy, spacerujemy, bawimy się, kolorujemy itp ale ten czas z Uli- } \\
\text { cą Sezamkową to dla mnie bajka :)))). }\end{array}$ & $\begin{array}{l}\text { E } \\
\text { DH }\end{array}$ & $\begin{array}{l}{[\mathrm{E}]} \\
(\mathrm{A})+ \\
\text { (B) + duma, edu } \\
(\mathrm{C})- \\
{[\mathrm{DH}]} \\
(\mathrm{A})+ \\
(\mathrm{B})- \\
\text { (C) + bezruch }\end{array}$ \\
\hline
\end{tabular}




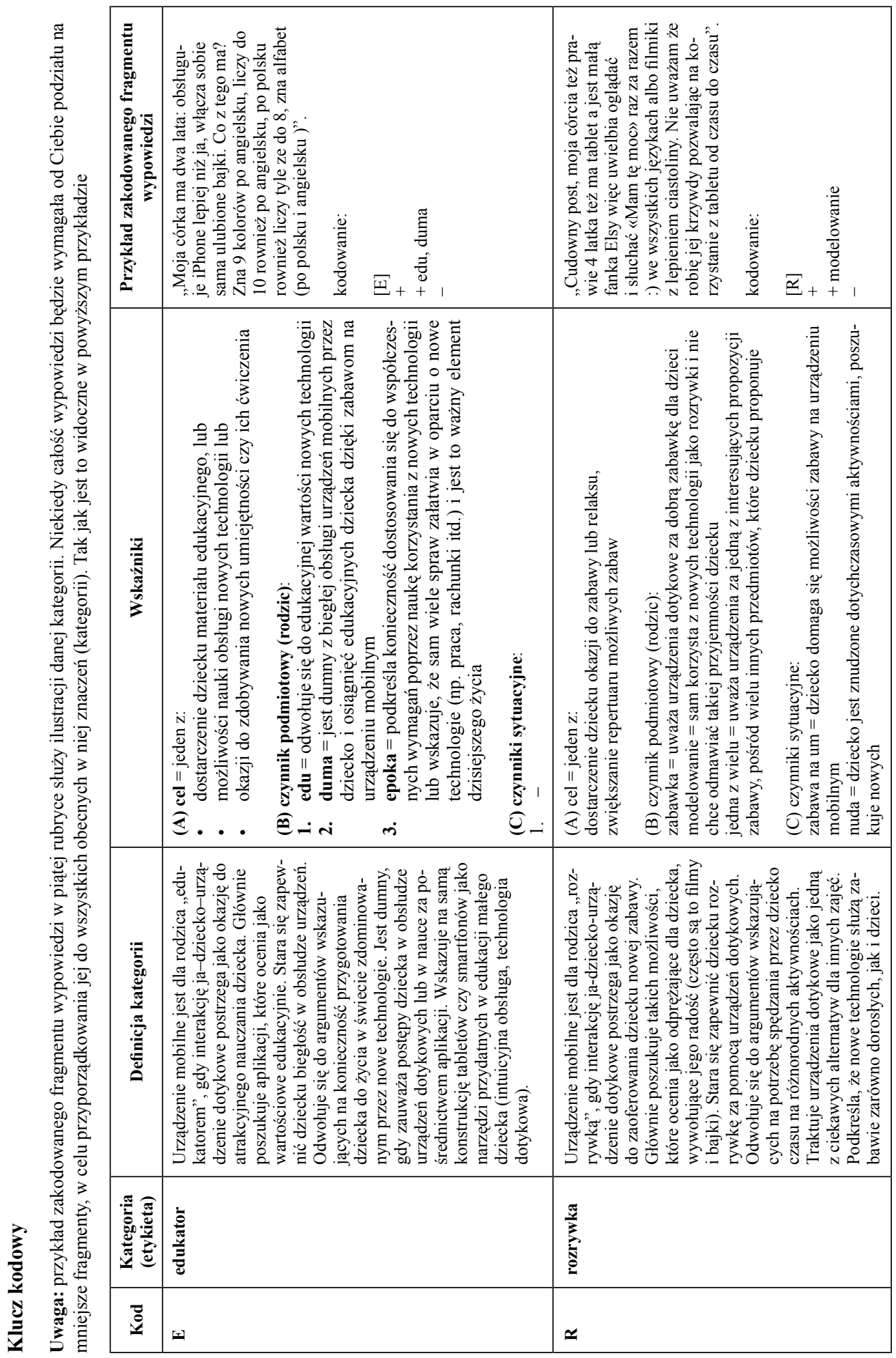




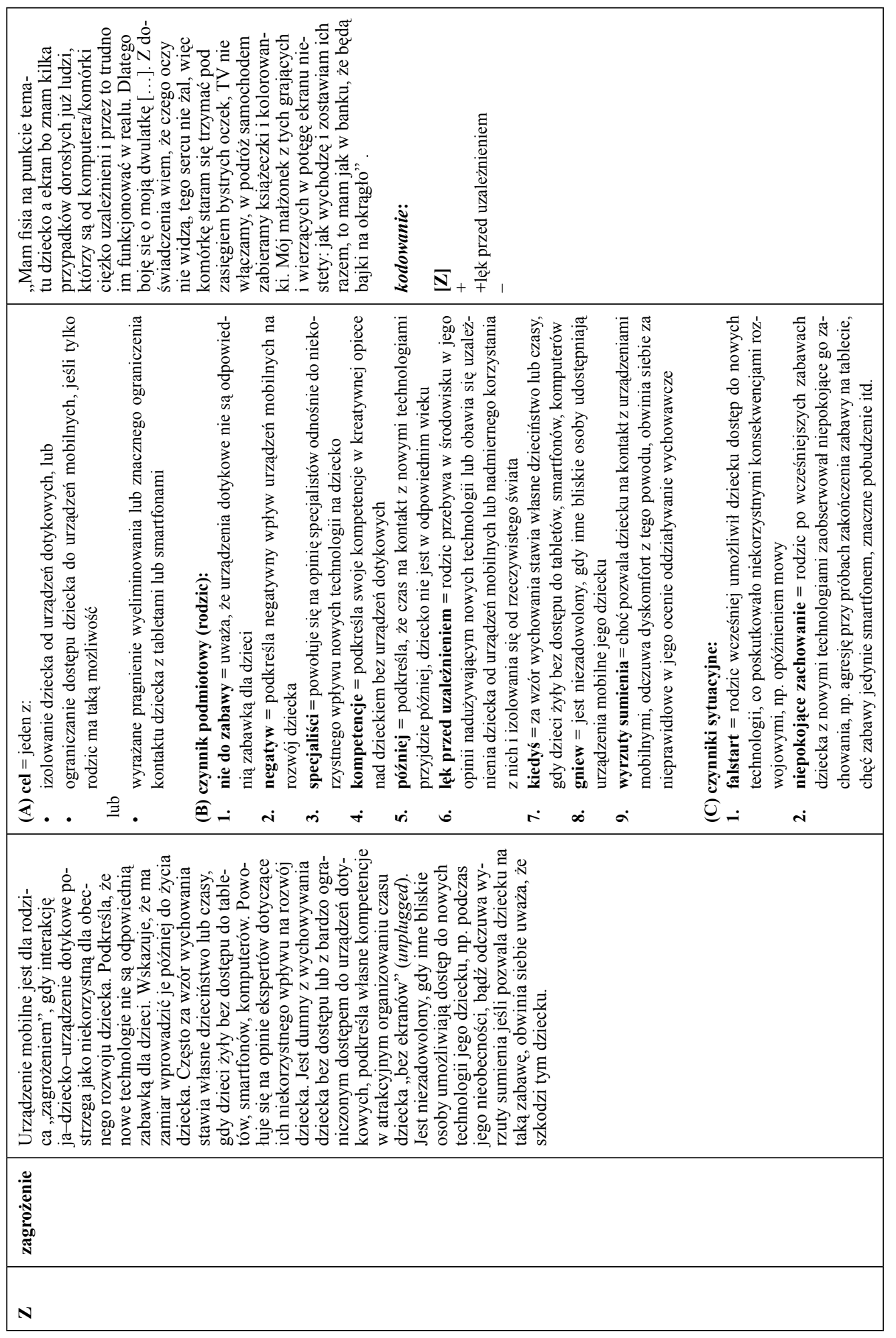




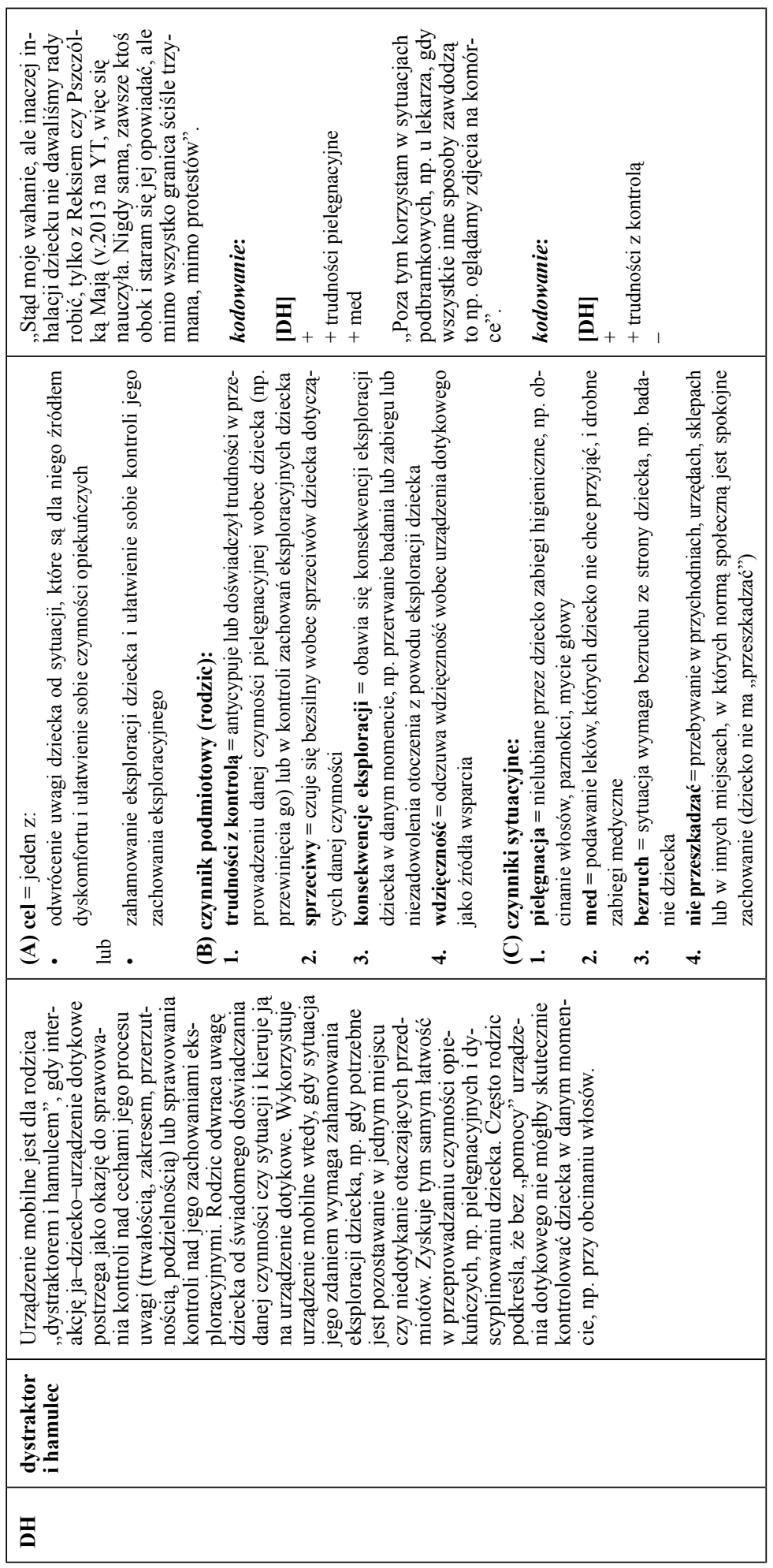




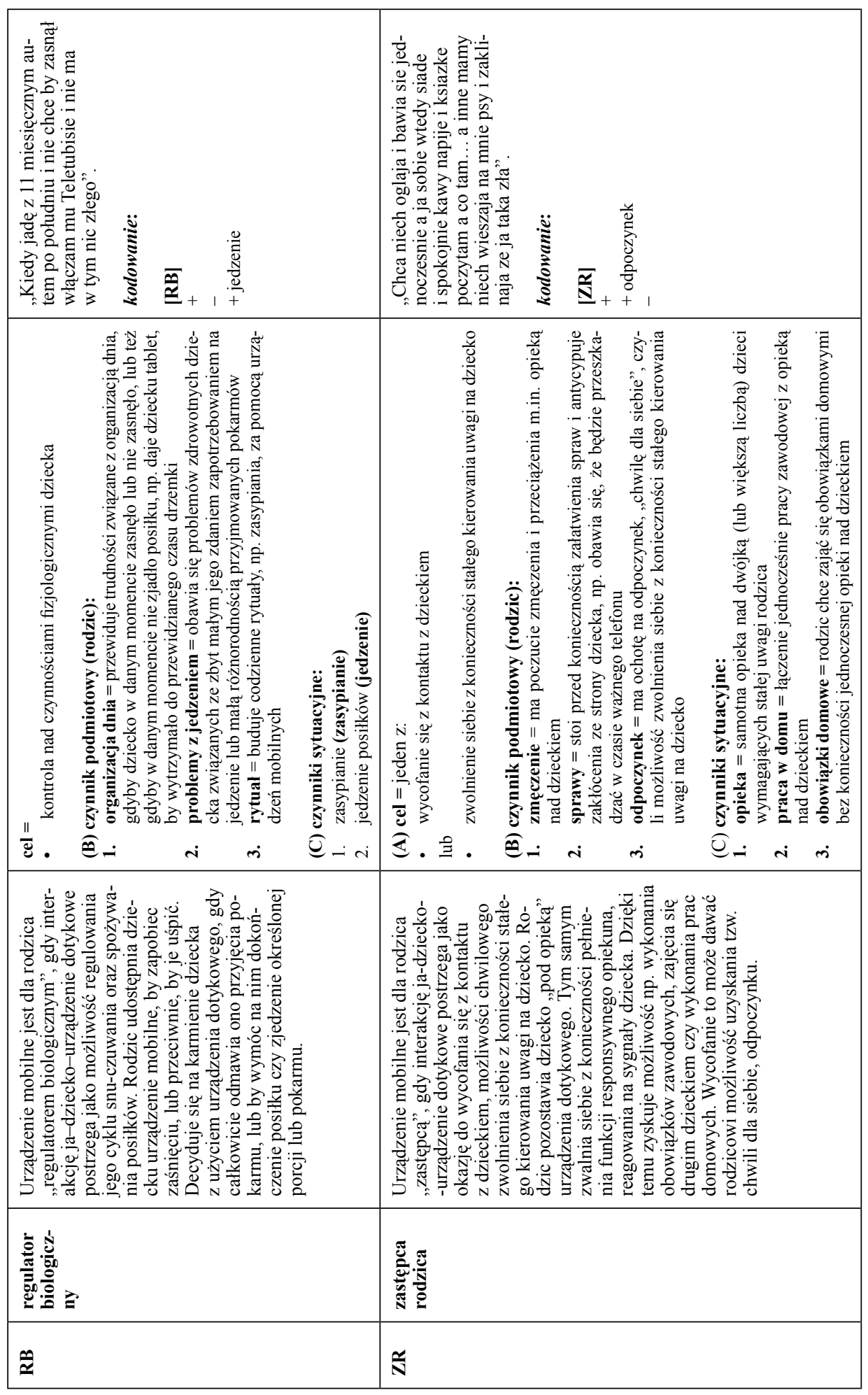




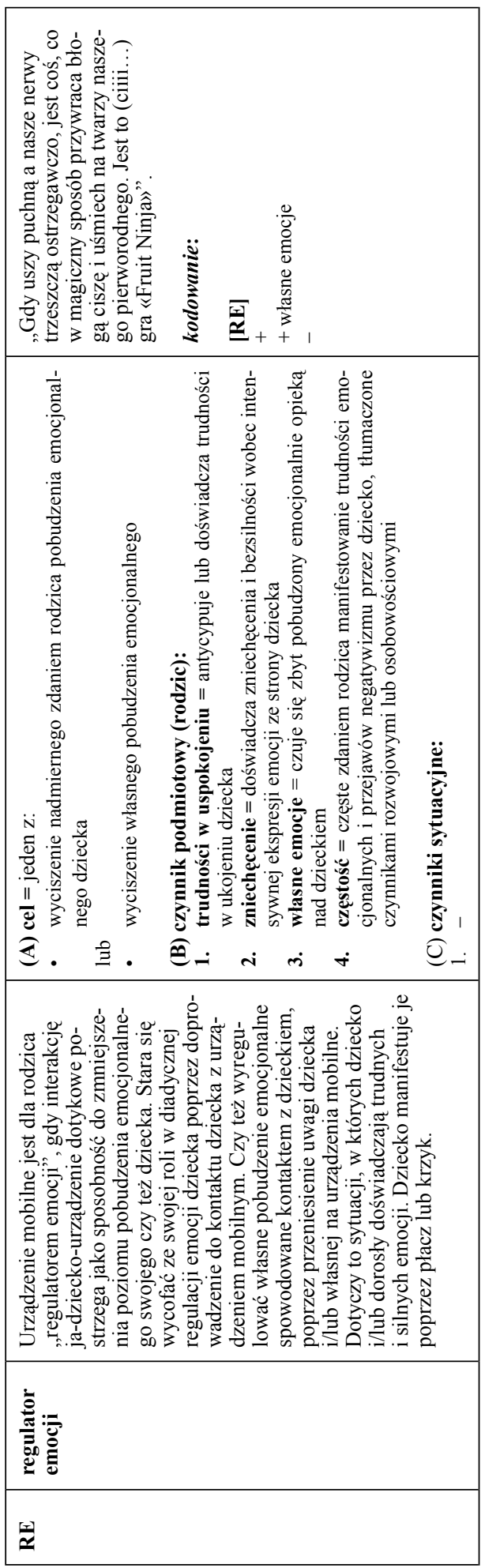

